\title{
Analysis of the repeatability of the exhaust pollutants emission research results for cold and hot starts under controlled driving cycle conditions
}

\author{
Artur Jaworski ${ }^{1} \cdot$ Hubert Kuszewski $^{1} \cdot$ Adam Ustrzycki $^{1} \cdot$ Krzysztof Balawender $^{1} \cdot$ Kazimierz Lejda $^{1} \cdot$ Paweł Woś $^{1}$
}

Received: 4 November 2017 / Accepted: 9 April 2018 / Published online: 20 April 2018

(C) The Author(s) 2018

\begin{abstract}
Measurement of car engines exhaust pollutants emissions is very important because of their harmful effects on the environment. This article presents the assessment of repeatability of the passenger car engine exhaust pollutants emission research results obtained in the conditions of a chassis dynamometer. The research was conducted in a climate chamber, enabling the temperature conditions to be determined from -20 to $+30{ }^{\circ} \mathrm{C}$. The emission of $\mathrm{CO}, \mathrm{CH}_{4}, \mathrm{CO}_{2}, \mathrm{NO}_{\mathrm{X}}, \mathrm{THC}$, and NMHC was subjected to the analysis. The aim of the research is to draw attention to the accuracy of the pollutant emission research results in driving cycles, and the comparison of pollutant emission results and their repeatability obtained in successive NEDC cycles under cold and hot start conditions. The results of the analysis show that, in the case of a small number of measurements, the results repeatability analysis is necessary for a proper interpretation of the pollutant emission results on the basis of the mean value. According to the authors' judgment, it is beneficial to determine the coefficient of variation for a more complete assessment of exhaust emission result repeatability obtained from a small number of measurements. This parameter is rarely presented by the authors of papers on exhaust components emission research.
\end{abstract}

Keywords Vehicle emissions $\cdot$ Exhaust measurements $\cdot$ Repeatability $\cdot$ Cold start test $\cdot$ Hot start test $\cdot$ Chassis dynamometer testing

\section{Introduction}

The harmful effects of transport on the environment are mainly related to the emission of gaseous and particulate pollutants

Responsible editor: Philippe Garrigues

\section{Artur Jaworski \\ ajaworsk@prz.edu.pl \\ Hubert Kuszewski \\ hkuszews@prz.edu.pl \\ Adam Ustrzycki \\ austrzyc@prz.edu.pl}

Krzysztof Balawender

kbalawen@prz.edu.pl

Kazimierz Lejda

klejda@prz.edu.pl

Paweł Woś

pwos@prz.edu.pl

1 Faculty of Mechanical Engineering and Aeronautics, Department of Combustion Engines and Transport, Rzeszow University of Technology, 8 Powstancow Warszawy Ave, 35-959 Rzeszow, Poland by internal combustion engines. For many years, work has been conducted to minimize energy consumption and reduce exhaust pollutants emissions. This also applies to the introduced emission standards and testing procedures for internal combustion engines. In the case of passenger cars and light commercial vehicles, Euro procedures, which include standards for exhaust pollutants emissions during driving cycles, under controlled conditions, on a chassis dynamometer, and road tests apply in the European Union (European Commission E 2007, 2015, 2017).

Limited reserves of crude oil, which is the primary raw material for the production of gasoline and diesel, imply the search for replacement fuels. Their introduction should not result in an increase in exhaust pollutants emissions above the limit levels specified in the standards.

The emissions researches conducted by different laboratories show large differences in the values of the research results. This is due to the very high number of factors that affect the exhaust components emission levels (Joumard et al. 2013). Those are the factors related to the research equipment used, the object of the research and their conditions. The main factor on which the pollutant emissions level depends is the driving cycle. Currently, new models of cars should go through 
Fig. 1 Climatic chassis dyno exhaust measurement system

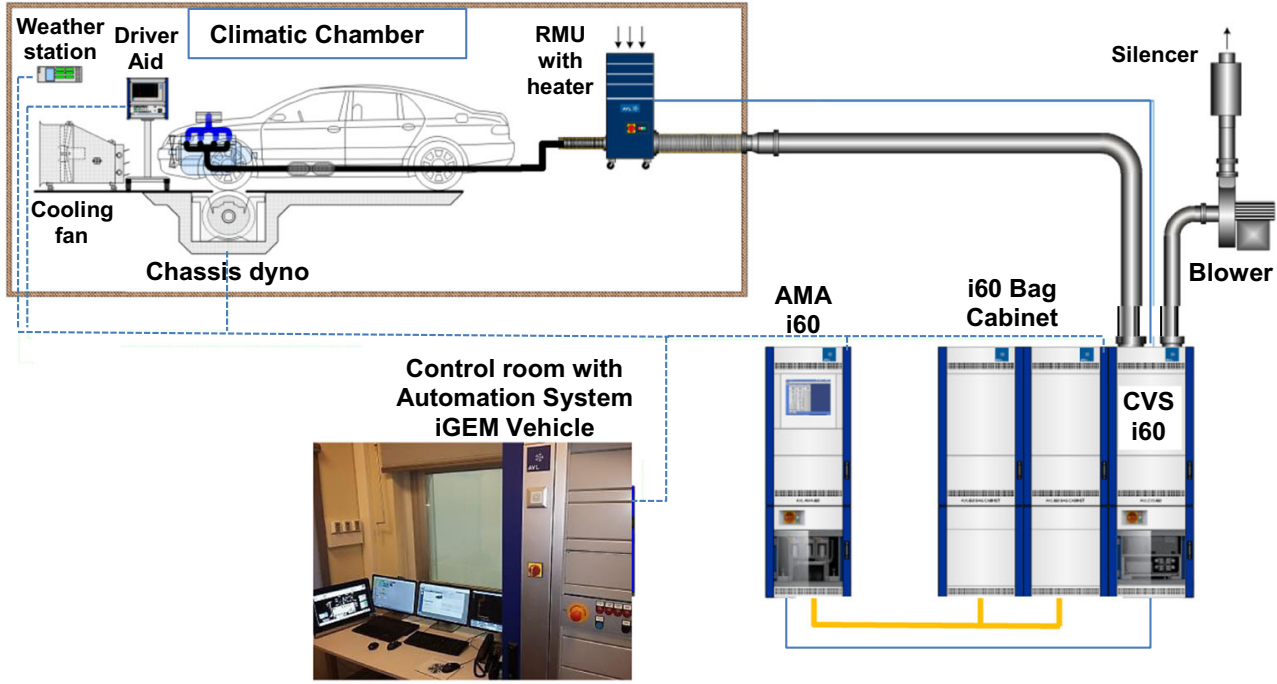

legislative research in accordance with WLTP (World Harmonized Light Vehicle Research Procedure), in which WLTC cycles (World Harmonized Light Vehicles Test Cycle) replace the NEDC test (European Commission E 2017; Heinfellner et al. 2016). More emphasis is placed on the tests that involve the cycles that are more closely related to real-time driving cycles present on the roads (Pielecha et al. 2016; Merkisz and Rymaniak 2017), reproduced on the dynamometer bench, or the conduct of research organized on the road (RDE-Real Driving Emissions). However, there are divergent data on the emission levels differences derived from NEDC and WLTC tests. According to papers (Pelkmans and Debal 2006; May et al. 2014), the emission of pollutants in real traffic conditions is often higher than for NEDC. Also in WLTP-compliant tests (Marotta et al. 2015), higher emission factors were reported for the entire test compared with NEDC for $\mathrm{CO}$ and $\mathrm{NO}_{\mathrm{X}}$ in the case of gasoline engines, and for $\mathrm{NO}_{\mathrm{X}}$ in the case of diesel engines. On the other hand, in paper (Mast 2014), $\mathrm{NO}_{\mathrm{X}}$ emission in the case of a petrol engine was lower for the entire WLTC test than for NEDC. Comparative tests of

Table 1 Basic technical data of AVL ROADSIM 48" chassis dynamometer (AVL 2014)

\begin{tabular}{ll}
\hline Analyzed quantity & Value \\
\hline Rated power & $153 \mathrm{~kW}$ \\
Instantaneous power & $258 \mathrm{~kW}$ \\
Maximum speed & $200 \mathrm{~km} / \mathrm{h}$ \\
Maximum continuous tractive force & $5987 \mathrm{~N}$ \\
Maximum instantaneous tractive force & $10,096 \mathrm{~N}$ \\
Tractive force measurement error & $\leq 0.1 \%$ \\
Speed measurement error & $\leq 0.02 \mathrm{~km} / \mathrm{h}$ \\
Distance measurement error & $0.001 \% / \mathrm{m}$ \\
\hline
\end{tabular}

the exhaust pollutants emissions for NEDC and WLTC tests are also the object of numerous papers (Andersson et al. 2014; May et al. 2014; Bielaczyc et al. 2014, 2015; Ligterink et al. 2016). However, it is difficult to compare the emission results obtained from the tests with significantly different parameters.

A difficulty with regard to the research testing is still the question of determining the distribution of the research results. For the tests conducted on public roads, in real traffic conditions, it is difficult to talk about high repeatability. Therefore, tests on dynamometers, including those based on NEDC tests, remain favorable in relation to such $\mathrm{R} \& \mathrm{D}$ tests, for which their differences of results are not large.

Because in many cases the influence of introduced structure and operating changes on fuel consumption and emission of engine exhaust pollutants is low (Concave 2016; Martini et al. 2013), it is important to determine the accuracy of the conducted researches. Pollution emissions tests conducted on the

Table 2 Specification of used AVL CVS i60 GD system (AVL 2010)

\begin{tabular}{ll}
\hline Parameter & CVS i60 GD \\
\hline Flow rate & \\
$\quad$ Diluted exhaust & $\operatorname{max~} 30 \mathrm{~m}^{3} / \mathrm{min}$ \\
$\quad$ Bag fill rate & $\approx 4 ; 6 ; 101 / \mathrm{min}$ \\
$\quad$ Absolute pressure sensor measurement & $700-1100 \mathrm{hPa}$ \\
$\quad$ range & $\pm 0.25 \%$ of the set range \\
Absolute pressure sensor measurement & \\
$\quad$ quality & $0-200 \mathrm{hPa}$ \\
Difference pressure sensor measurement & \\
$\quad$ range & $273-373 \mathrm{~K}$ \\
Temperature sensor measurement range & $\pm 1 \mathrm{~K}$ \\
$\quad$ Temperature sensor measurement quality & $0-100 \%$ rel. air \\
Humidity sensor measurement range & humidity \\
&
\end{tabular}


Table 3 Specification of used AMA i60 analysers (AVL 2013)

\begin{tabular}{|c|c|c|c|c|}
\hline Parameterlanalyzer & CLD i60 LD & FID i60 LCD & IRD i60 $\mathrm{CO}_{2} \mathrm{~L}$ & IRD i60 L \\
\hline $\begin{array}{l}\text { Measured } \\
\text { components }\end{array}$ & $\mathrm{NO}$ and $\mathrm{NO}_{\mathrm{X}}$ & $\mathrm{THC}$ and $\mathrm{CH}_{4}$ & $\mathrm{CO}_{2}$ & $\mathrm{CO}$ \\
\hline Noise & $\leq 1 \%$ of range full scale & $\leq 0.5 \%$ of range full scale & $\leq 1 \%$ of range full scale & $\leq 1 \%$ of range full scale \\
\hline Drift & $\leq 1 \%$ of range full scale $/ 24 \mathrm{~h}$ & $\leq \%$ of range full scale $/ 24 \mathrm{~h}$ & $\leq 1 \%$ of range full scale $/ 24 \mathrm{~h}$ & $\leq 1 \%$ of range full scale $/ 24 \mathrm{~h}$ \\
\hline Reproducibility & $\leq 0.5 \%$ of range full scale & $\leq 0.5 \%$ of range full scale & $\leq 0.5 \%$ of range full scale & $\leq 0.5 \%$ of range full scale \\
\hline \multirow[t]{2}{*}{ Linearity } & $\begin{array}{l}\leq 2 \% \text { of measured value } \\
\quad(10-100 \% \text { of range full scale })\end{array}$ & $\begin{array}{l}\leq 2 \% \text { of measured value } \\
\quad(10-100 \% \text { of range full scale })\end{array}$ & $\begin{array}{l}\leq 2 \% \text { of measured value } \\
\quad(10-100 \% \text { of range full scale })\end{array}$ & $\begin{array}{l}\leq 2 \% \text { of measured value } \\
\quad(10-100 \% \text { of range full scale })\end{array}$ \\
\hline & $\begin{array}{l}\leq 1 \% \text { of range full scale } \\
\text { whichever is smaller }\end{array}$ & $\begin{array}{l}\leq 1 \% \text { of range full scale } \\
\text { whichever is smaller }\end{array}$ & $\begin{array}{l}\leq 1 \% \text { of range full scale } \\
\text { whichever is smaller }\end{array}$ & $\begin{array}{l}\leq 1 \% \text { of range full scale } \\
\text { whichever is smaller }\end{array}$ \\
\hline
\end{tabular}

chassis dynamometer are a very complex emission. The test results depend, among other things, on the reproducibility of the driving cycle conducted by the car driver, the climatic conditions, the physicochemical properties of the fuel, the engine and vehicle design and operating parameters, and the accuracy of the used test equipment. A broad analysis of the influence of the selected factors on the pollutants emission in the research tests is included in the paper of Joumard et al. (2013).

The pollution emissions research conducted in road conditions or on the chassis dynamometer are very expensive, which is connected mainly with the high costs of the test equipment, the costs of electricity, and working gases. Therefore, the question of the minimum number of measurements that must be conducted to make the test result acceptable, arises. In the case of approval tests, according to the regulations (European Commission E 2007, 2015, 2017), the number of emission measurements for a type 1 test, depending on the results obtained, may be one, two, or three. For this reason, it is very important for the

Table 4 Technical data of the tested vehicle

\begin{tabular}{ll}
\hline Parameter & Value \\
\hline Length/width/height & $4665 / 1760 / 1445 \mathrm{~mm}$ \\
Wheelbase & $2670 \mathrm{~mm}$ \\
Weight & $1430 \mathrm{~kg}$ \\
Engine type & Petrol (gasoline) \\
Fuel System & Multi-point injection \\
Engine displacement & $1998 \mathrm{~cm}^{3}$ \\
Engine power & $115 \mathrm{~kW} @ 6000 \mathrm{rpm}$ \\
Engine torque & $190 \mathrm{~N} \mathrm{~m} @ 4500 \mathrm{rpm}$ \\
Number of cylinders & 4 \\
Number of valves & 16 \\
Emission standard & Euro 4 \\
Wheel drive & Front \\
Number of gears (manual transmission) & 5 \\
Tyre size & $205 / 55 \mathrm{R} 16$ \\
\hline
\end{tabular}

accuracy and repeatability of the measurements that they be performed under repeatable conditions, which include:

- Use of the same test method

- Tests in the same laboratory

- Tests conducted by the same operator

- Tests with the same equipment

- Short-term tests

The engine's thermal state is a factor that has a significant influence on the exhaust pollutants emission test results (Bielaczyc et al. 2001; Kwak et al. 2007; Kan et al. 2017). It involves both the engine control strategy (including fuel injection, ignition) and the catalytic converter efficiency. Such a large number of factors, each of which has a specific range of values, results in variability of results. Therefore, it is important to determine the extent of repeatability of the results for a given research method when conducting the research to determine the effect of design or operational changes on the exhaust pollutants emission. The accuracy of the pollutant emission research results is the object of many

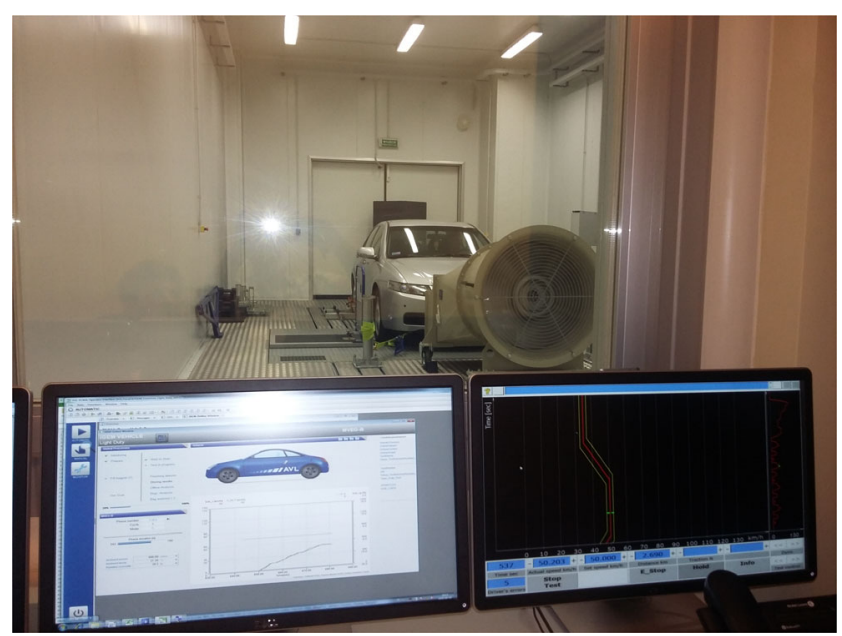

Fig. 2 A view of the car on the research set-up 


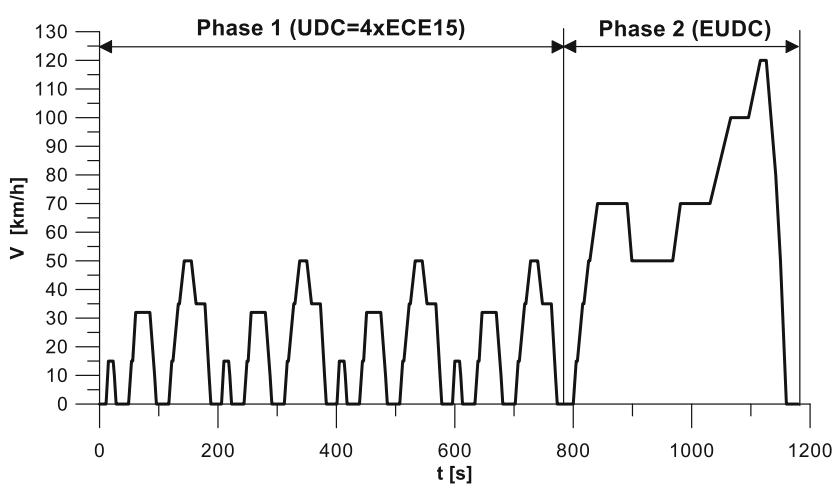

Fig. 3 NEDC test cycle

paper, e.g. (Myung et al. 2009; Chłopek and Rostkowski 2015; Chłopek and Szczepański 2015; Giechaskiel et al. 2008; Joumard et al. 2009, 2013; Suarez-Bertoa et al. 2014, 2015; Balawender et al. 2016; McCormick et al. 2006; Kim and Lee 2011).

Because the highest harmfulness of exhaust pollutants occurs in areas of densely populated cities, particular attention should be paid to the emission of toxic compounds in the urban part of the driving cycles and the evaluation of the accuracy of the results obtained.

This paper presents the analysis of the repeatability of the results for the exhaust pollutants emission test in a passenger car engine, powered by gasoline, according to the NEDC procedure. The tests were conducted from the cold and hot starts of the engine. The aim of the research is to emphasize the importance of repeatability of the exhaust pollutants emission tests, in particular for a small number of measurements. Attention has also been drawn to the often overlooked coefficient of variation $(\mathrm{CV})$, which allows for a more accurate assessment of the test results. The authors believe that determination of the coefficient of variation should be helpful in assessing the reproducibility of results obtained by various laboratories. There are currently no standards for specifying a satisfactory value of variation coefficients regarding exhaust emission research in stationary tests of motor vehicles.
Table 6 Hot start emission results (bag emissions)

\begin{tabular}{|c|c|c|c|}
\hline \multirow[t]{2}{*}{ Pollutants } & \multicolumn{3}{|c|}{ Emissions results $(\mathrm{g} / \mathrm{km})$} \\
\hline & Test 4 & Test 5 & Test 6 \\
\hline THC & 0.0055 & 0.0056 & 0.0085 \\
\hline NMHC & 0.0028 & 0.0026 & 0.0051 \\
\hline $\mathrm{CH}_{4}$ & 0.0028 & 0.0032 & 0.0034 \\
\hline $\mathrm{NO}_{\mathrm{X}}$ & 0.0057 & 0.0023 & 0.0086 \\
\hline $\mathrm{CO}$ & 0.15 & 0.16 & 0.19 \\
\hline $\mathrm{CO}_{2}$ & 185.4 & 186.5 & 186.9 \\
\hline
\end{tabular}

\section{Experimental methodology}

\section{Experimental equipment}

The research bench is located in the Laboratory of Automotive Ecology at the Faculty of Mechanical Engineering and Aeronautics, of the Rzeszow University of Technology (Fig. 1). The Department of Combustion Engines and Transport of the Rzeszow University of Technology has worked for many years now to reduce the harmful effects of transport on the environment. This concerns the improvement of the internal combustion engines and vehicles design, and the search for alternative fuels (Kuszewski et al. 2017a, b). At present, exhaust pollutants emission testing for passenger car engines is conducted. The tests are conducted on the engine dynamometer, in real road conditions and under controlled climatic conditions according to the European NEDC driving cycle.

The tests concerning the paper in question were conducted on the chassis dynamometer Zoellner ROADSIM 48 manufactured by AVL built in a climate chamber. The basic specifications of the chassis dynamometer are provided in Table 1.

The AVL climate chamber enables temperatures between -20 and $+30^{\circ} \mathrm{C}$. The measurement bench includes the AVL CVS i60 exhaust dilution system and the AVL AMA i60
Table 5 Cold start emission results (bag emissions) and the limits (standards Euro 4)

\begin{tabular}{|c|c|c|c|c|}
\hline \multirow[t]{2}{*}{ Pollutants } & \multicolumn{3}{|c|}{ Emissions results $(\mathrm{g} / \mathrm{km})$} & \multirow{2}{*}{$\begin{array}{l}\text { EU Emission Standards for } \\
\text { passenger cars using } \\
\text { gasoline engines }(\mathrm{g} / \mathrm{km})\end{array}$} \\
\hline & Test 1 & Test 2 & Test 3 & \\
\hline THC & 0.046 & 0.046 & 0.051 & 0.1 \\
\hline NMHC & 0.041 & 0.041 & 0.046 & - \\
\hline $\mathrm{CH}_{4}$ & 0.0047 & 0.0048 & 0.0049 & - \\
\hline $\mathrm{NO}_{\mathrm{X}}$ & 0.02 & 0.019 & 0.016 & 0.08 \\
\hline $\mathrm{CO}$ & 0.439 & 0.441 & 0.448 & 1.0 \\
\hline $\mathrm{CO}_{2}$ & 201.411 & 202.796 & 203.332 & - \\
\hline
\end{tabular}


Fig. 4 Results of the $\mathrm{CO}_{2}$ emission obtained for three tests (from a cold start and from a hot start)

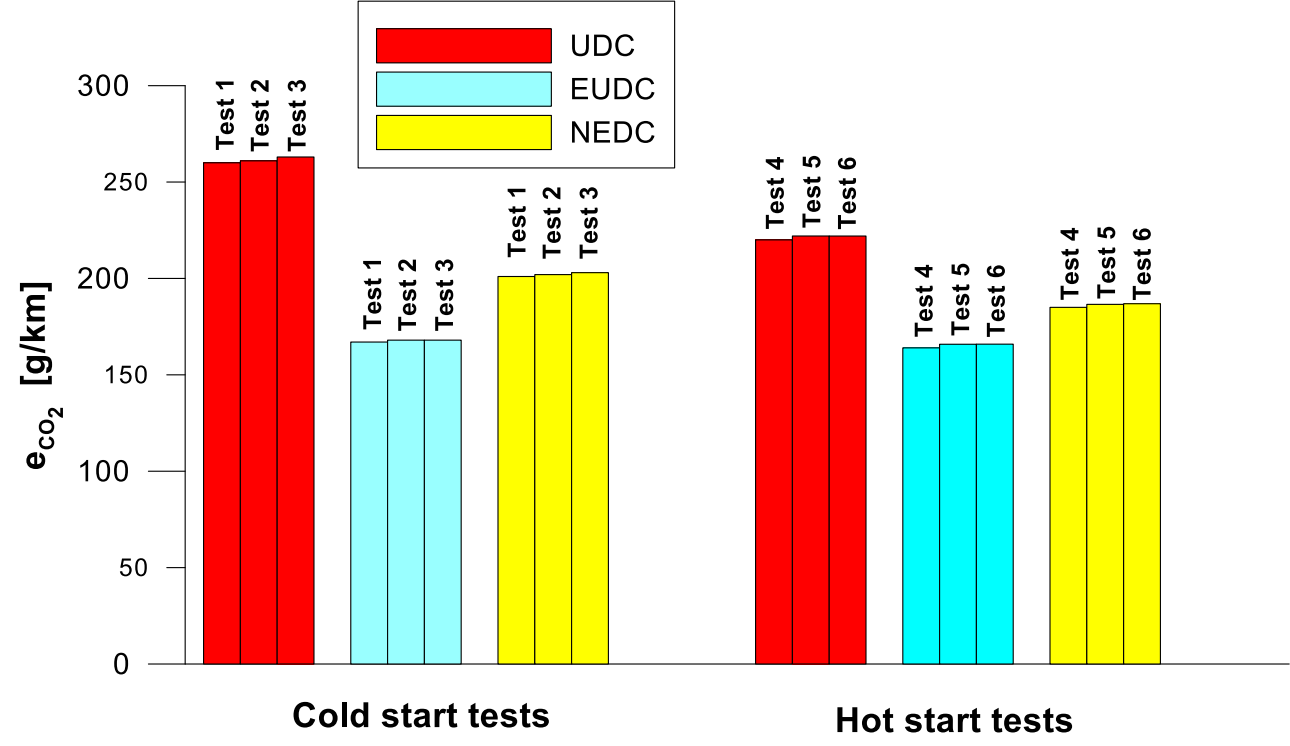

exhaust analysis system. The basic data of those systems are summarized in Tables 2 and 3.

The object of the test was a passenger car manufactured in 2003 with a mileage of $\approx 60,000 \mathrm{~km}$, whose basic specifications are shown in Table 4. To obtain the simulated road load maximally close to the resistance of the real road, coast-down tests have been conducted, which were implemented in the speed range from $130 \mathrm{~km} / \mathrm{h}$ to zero. A non-contact system with optical sensor DATRON DLS-2 was used for the measurement of the coast-down parameters. Based on the determined coast-down times, the following equation of the road load was determined:

$F_{0}=155.11-1.2343 \mathrm{~V}+0.4685 \mathrm{~V}^{2}$

where $F_{o}$ is the road load $(N)$ and $V$ is the vehicle speed $(\mathrm{km} / \mathrm{h})$.
View of the tested car on the research set-up is shown in Fig. 2.

\section{Research methodology}

The tests were performed according to the NEDC test procedure, which consists of two phases: UDC and EUDC (Fig. 3). The tests were performed from a cold start and hot start. Before cold start measurements, the car was conditioned for a period of 6 to $12 \mathrm{~h}$ in a climate chamber of $21 \pm 1^{\circ} \mathrm{C}$ and relative humidity of $40 \pm 1 \%$. In the case of hot start tests, the engine coolant temperature before the test was $90 \pm 2{ }^{\circ} \mathrm{C}$.

The exhaust pollutants emission measurements were conducted with a constant volume sampling system (CVS i60). Prior to each test, the exhaust analysis system was calibrated.
Fig. 5 Results of the $\mathrm{CO}$ emission obtained for three tests (from a cold start and from a hot start)

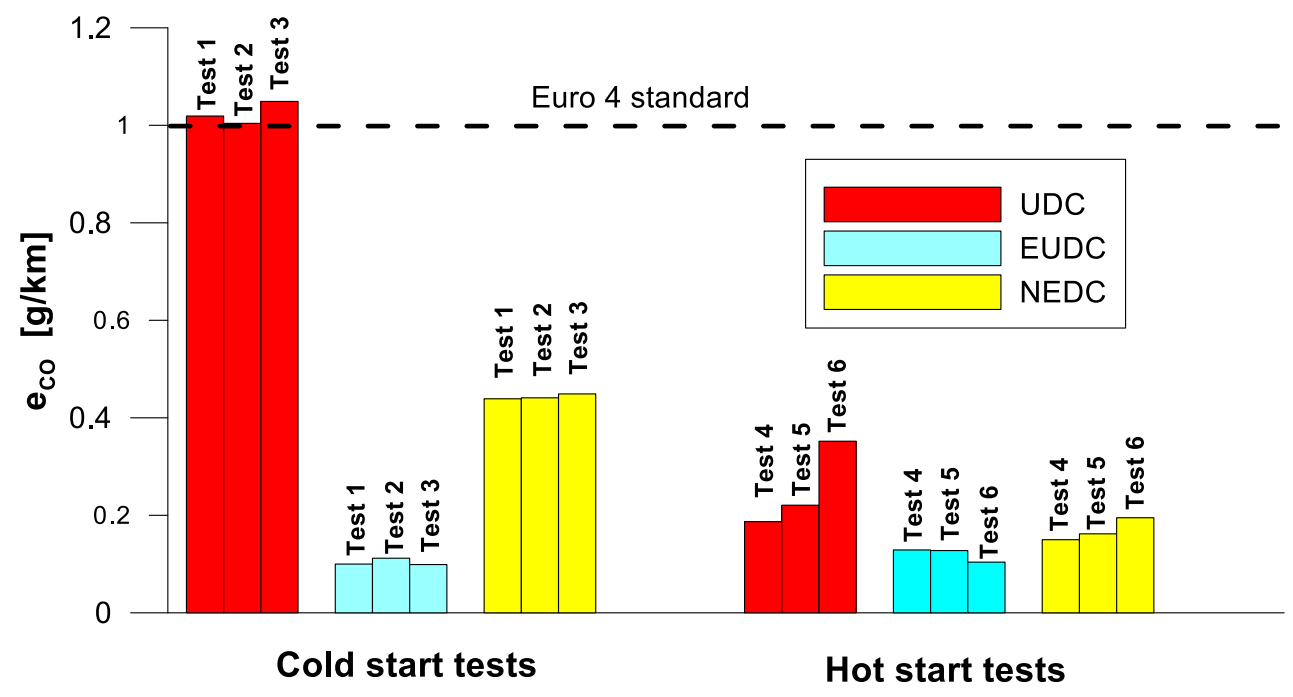


Fig. 6 Results of the $\mathrm{NO}_{\mathrm{X}}$ emission obtained for three tests (from a cold start and from a hot start)

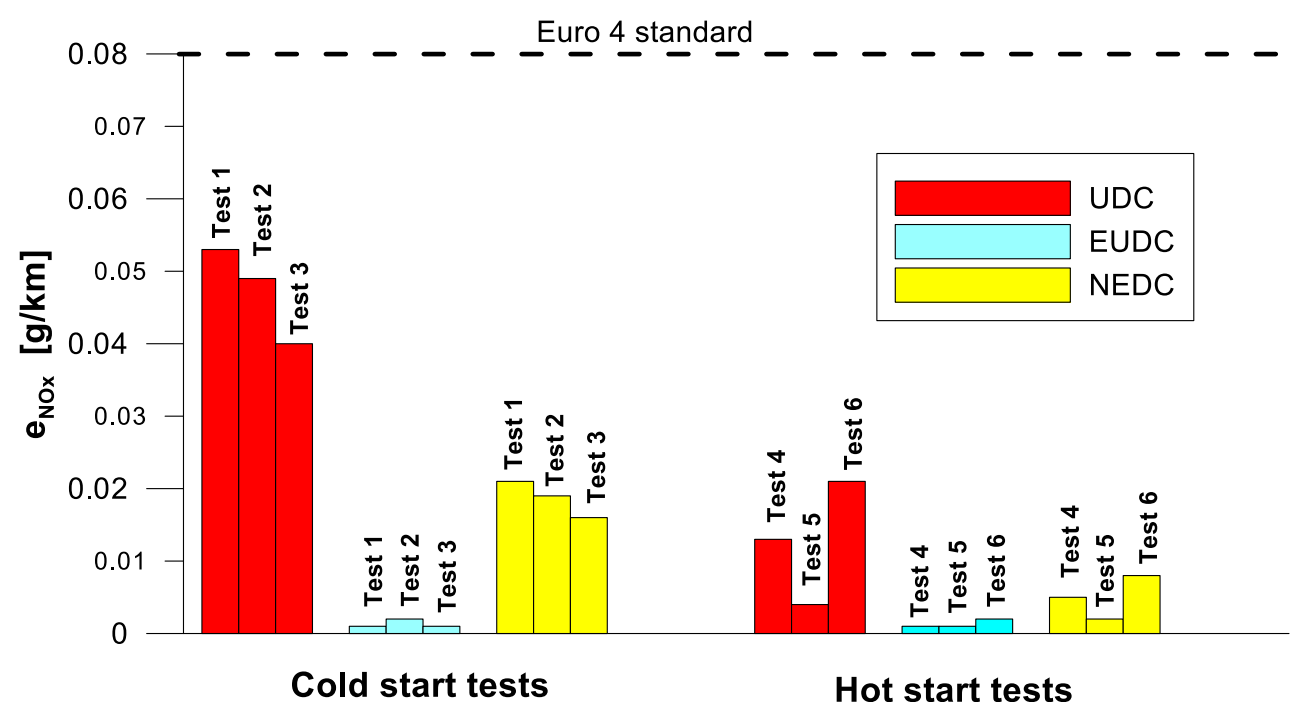

The air diluted exhaust was directed during the bag analysis cycle and the modal analysis, i.e., measurement of diluted exhaust concentrations, was performed in parallel using an AVL AMA i60 exhaust analysis system. After the test completion, the pollutant emissions average values, for the below exhaust components were calculated in individual phases (UDC, EUDC, NEDC): THC, $\mathrm{CH}_{4}, \mathrm{NMHC}, \mathrm{NO}_{\mathrm{X}}, \mathrm{CO}, \mathrm{CO}_{2}$. The tests were conducted using the AVL PUMA Open system with iGEM Vehicle software and with automatic exhaust emissions measurement.

2After a series of three cold start tests (tests 1-3) and three hot start tests (tests 4-6), the measurement method accuracy was analyzed and the repeatability of the test results was assessed.

The precision is defined as the degree of compatibility between independent test results obtained under the established conditions (PN-ISO 5725-1 2002; PN-ISO $5725-2,2002)$. The precision depends only on the distribution of random errors and there is no reference to the real value. Normally, the standard deviations of the test results, the values of which are the smaller the higher is the precision, constitute a measure for the precision.

Repeatability is the precision when the repeatability conditions are met. To evaluate the repeatability, the following parameters were determined:

- Measurement results average values $x_{\mathrm{av}}$

- Minimum values $x_{\min }$ and maximum values $x_{\max }$

- Range $R_{\mathrm{x}}$

- Standard deviation of repeatability $S_{\mathrm{r}}$

- Repeatability limit $r$

- Coefficient of variation CV
Fig. 7 Results of the THC emission obtained for three tests (from a cold start and from a hot start)

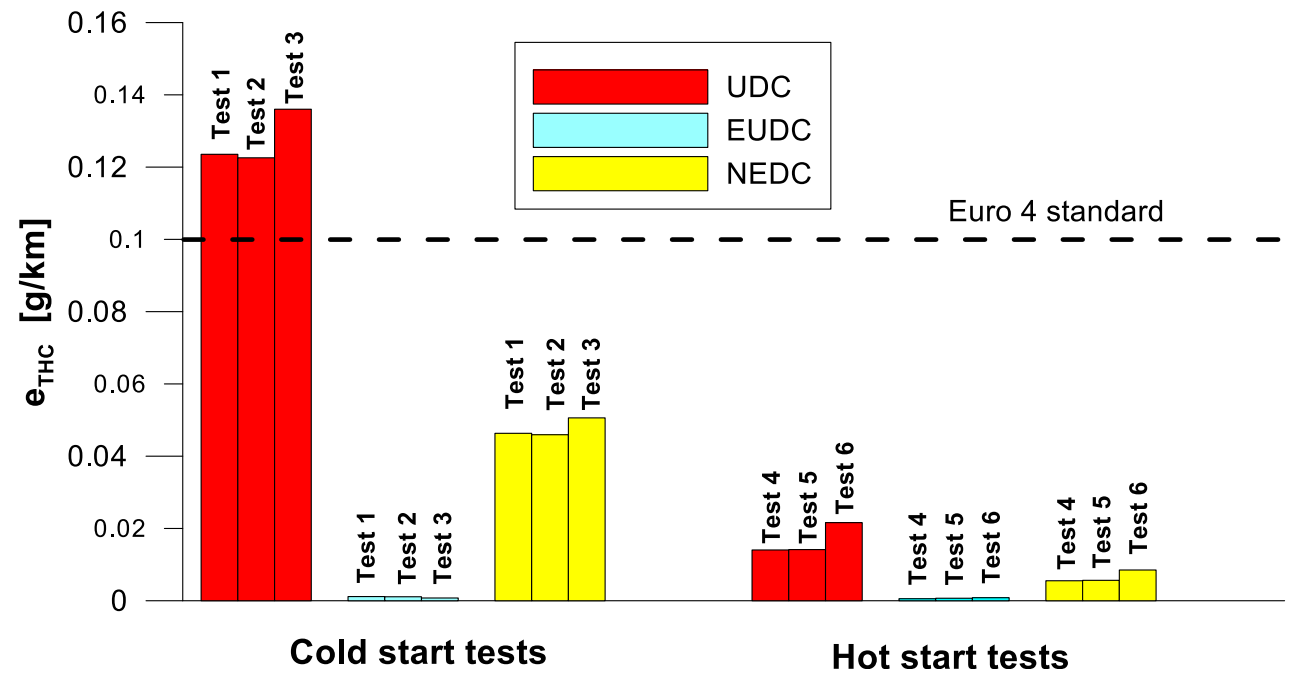


Fig. 8 Results of the $\mathrm{CH}_{4}$ emission obtained for three tests (from a cold start and from a hot start)

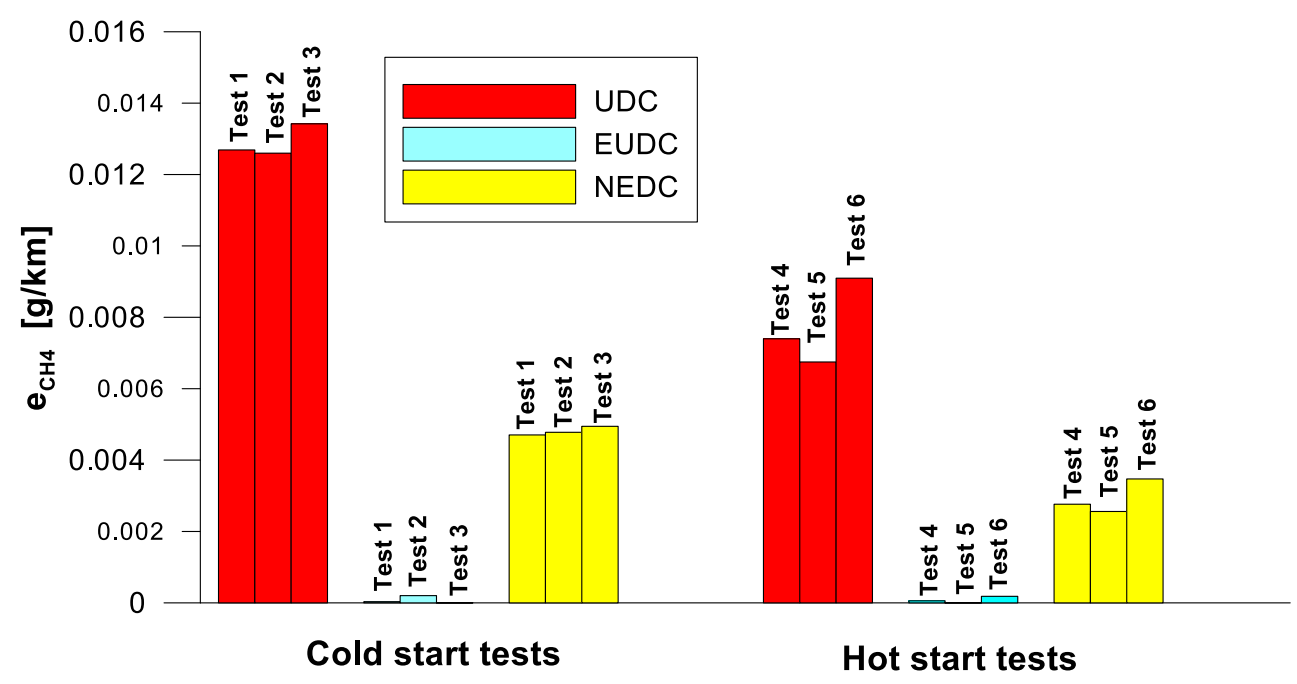

The standard deviation was accepted as a measure of the test results dispersion, which was calculated as follows:

$s_{r}=\left(\frac{\sum_{\mathrm{i}=1}^{\mathrm{n}}\left(x_{\mathrm{i}}-x_{a v}\right)^{2}}{n-1}\right)^{1 / 2}$

where $s_{\mathrm{r}}$ is the standard deviation of repeatability, $x_{i}$ is the result of the $i$-th measurement, $x_{\mathrm{av}}$ is the arithmetic mean of the results, and $n$ is the number of measurements.

The repeatability limit $r$ is defined as a value which, with a probability of $95 \%$, is not exceeded by the absolute value of the difference between the two tests results obtained when the repeatability conditions are met.

In the case of standardized methods, in normal laboratory practice, at least two parallel designations are executed, and the absolute difference between the results is compared with a certain critical value, which is the repeatability limit determined by the following formula (PN-ISO 5725-6 2002):

$r=2.8 \cdot s_{r}$

where $s_{\mathrm{r}}$ is the standard deviation of repeatability indicated for all the measurements.

It is recommended that the absolute difference of the measurement results does not exceed the repeatability limit. If this value does not exceed $r$, then each result is considered to be acceptable and their mean is given as the final result.

The relative value that was adopted to assess the unrepeatability of the measurement results of particular pollutants is the $\mathrm{CV}$, calculated from the following formula:

$\mathrm{CV}=\frac{s_{r}}{x_{\mathrm{av}}} \cdot 100$

The above measures were set for all emissions indicators of the analyzed exhaust components, both for the entire test as well as for the individual phases (UDC, EUDC).
Fig. 9 Results of the NMHC emission obtained for three tests (from a cold start and from a hot start)

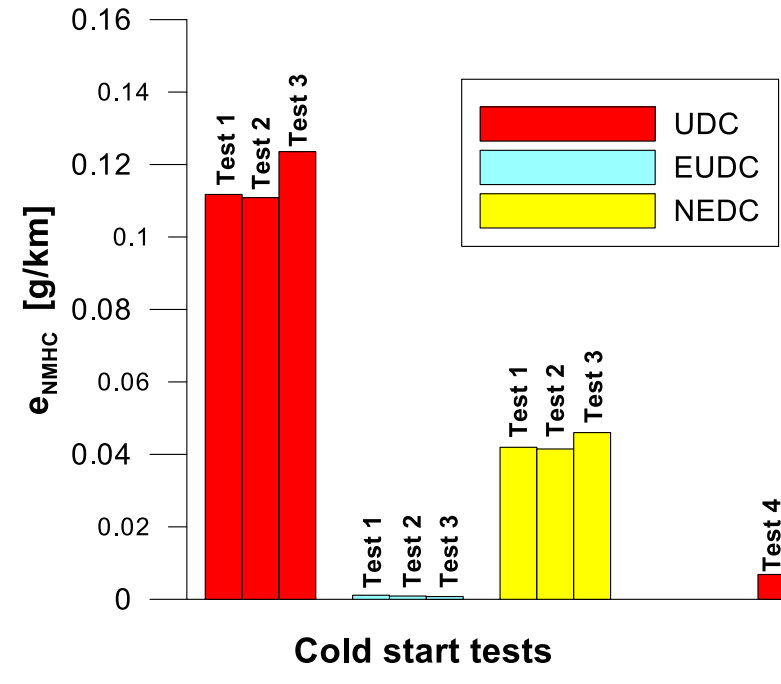


Fig. 10 The ratio of the average factor of emission from cold and hot starts for the UDC phase (average of three tests)

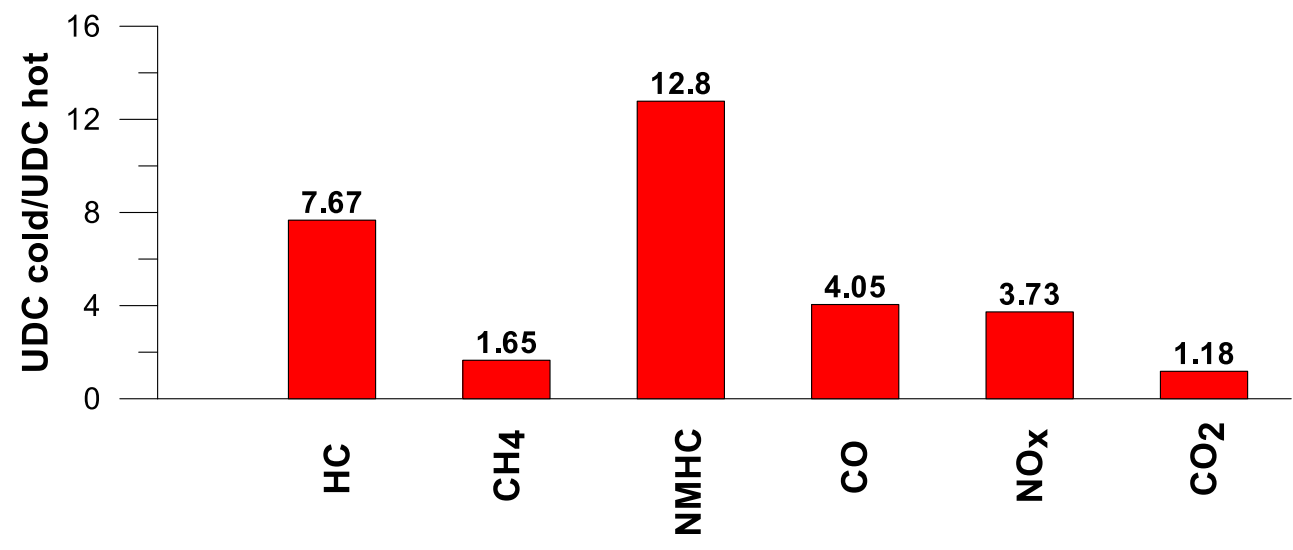

\section{Results and discussion}

The results for the emission of toxic pollutants in exhaust obtained in subsequent tests according to the NEDC test are presented in Table 5 (for cold start tests) and in Table 6 (for hot start tests). As the cold start test was conducted in accordance with the approved procedure, Euro 4 emission limit values are shown in Table 5.

Figures 4, 5, 6, 7, 8, and 9 compare the emission results of the analyzed pollutants in the exhaust for phase 1 (UDC), phase 2 (EUDC), and the entire test (NEDC).

The values of emission factors of the tested exhaust components are considerably higher in the urban part (UDC). In the case of the EUDC cycle, the emission factors were similar to those from cold and hot starts. This is due to the heating of the engine during the test (especially in the UDC phase during the cold start test). $\mathrm{CO}_{2}$ emission (Fig. 4) in the urban phase (UDC) is higher than in the EUDC emission, which is related to, e.g. higher average speed in the EUDC phase. By analyzing the graphs in Figs. 5 and 6, it can be seen that the $\mathrm{CO}$ and $\mathrm{NO}_{\mathrm{X}}$ emission values in the UDC part, in the hot start tests (tests 4-6), differ to a greater extent than in the cold start tests (tests 1-3). This may be due to the engine control strategy and the catalytic reactor efficiency. The results of the test included in paper (Favez et al. 2009) prove that in the examined cars the $\mathrm{CO}$ and $\mathrm{NO}_{\mathrm{X}}$ emissions from the warm engine may, in some phases of the test cycle, be higher than the emissions from the cold start test. According to the authors, this may be connected with the adopted engine control strategy.

However, as has been demonstrated in paper (Shamim 2011), the increase of the exhaust temperature is increased by the difference in the degree of conversion of toxic components $\left(\mathrm{NO}_{\mathrm{X}}, \mathrm{CO}, \mathrm{HC}\right)$ in the catalytic converter, depending on the air/fuel ratio. For lean mixtures $(\lambda>1)$, the average conversion efficiency of the NO for exhaust temperature $100{ }^{\circ} \mathrm{C}$ constituted $\approx 99 \%$, while for an exhaust temperature of $300{ }^{\circ} \mathrm{C}$ it was $\approx 6 \%$. In the case of $\mathrm{CO}$ and $\mathrm{HC}$, a low conversion efficiency of the catalytic converter occurs for the rich mixtures. The lower exhaust temperature, regardless of the composition of the blend, caused less variation in conversion efficiency of the catalytic converter (Shamim 2011).

With respect to normative emission levels (Euro 4), it is apparent that for all toxic components, i.e. $\mathrm{CO}$ (Fig. 5), $\mathrm{NO}_{\mathrm{X}}$ (Fig. 6), and $\mathrm{THC}$ (Fig. 7), the requirements are fulfilled. $\mathrm{CH}_{4}$ (Fig. 8) emission has the lowest value among the analyzed components.

Taking into account the values of the emission factors of exhaust components analyzed for cold and hot start tests
Fig. 11 The ratio of the average factor of emission from cold and hot starts for the EUDC phase (average of three tests)

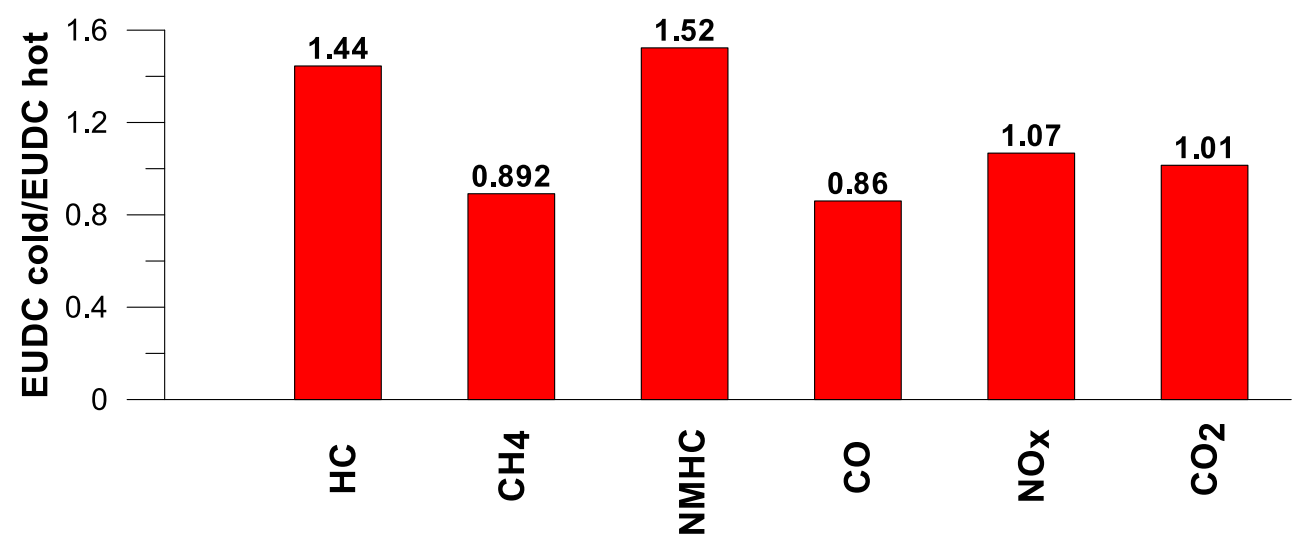


Fig. 12 The ratio of the average factor of emission from cold and hot starts for the NEDC cycle (average of three tests)

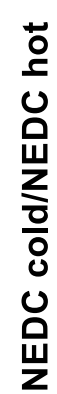

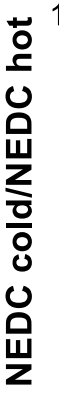

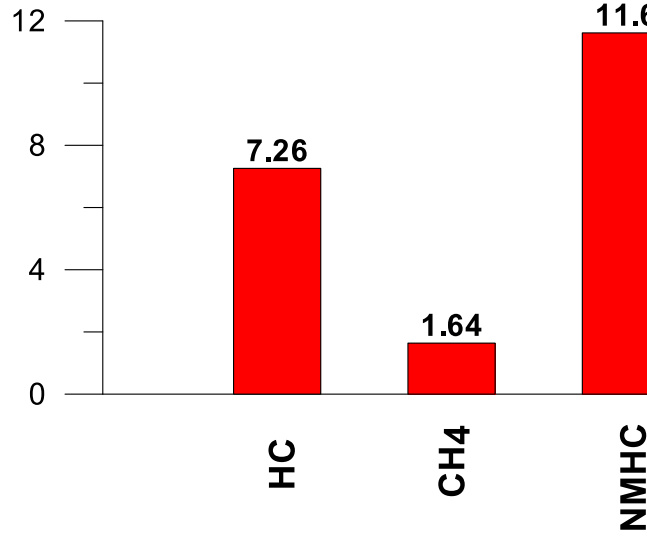

11.6

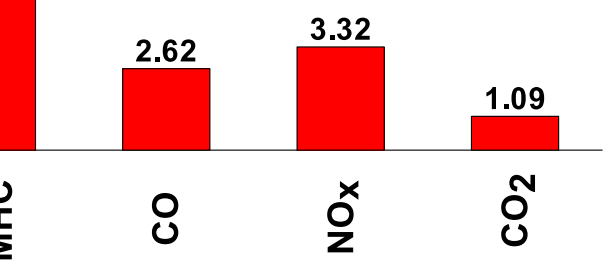

(Figs. 10, 11, and 12), it is apparent that, ignoring the emission of $\mathrm{CO}$ and $\mathrm{CH}_{4}$ in the second phase (for the EUDC cycle), lower emission for the hot start tests was obtained. For the NEDC tests performed for the hot start (Fig. 12), THC emission was approx. 7 times lower, and in the case of NMHC more than 11 times lower, than in the cold start tests. $\mathrm{NO}_{\mathrm{X}}$ emission was lower by more than 3 times, while $\mathrm{CO}_{2}$ emission was lower by $\approx 9 \%$. This is mainly related to the emission values obtained in the first phase of the cycle-UDC (Fig. 10), for which the differences in the exhaust pollutants emissions are the greatest. For the EUDC cycle (Fig. 11), the differences in the emissions factors from the cold and hot starts were small, which was largely due to the approximate thermal state of the engine being independent of the initial engine test temperatures. The analysis of temperature changes during the NEDC test conducted in the climate chamber $(T=$ $22{ }^{\circ} \mathrm{C}$ ), presented by the authors' paper (Torregrosa et al. 2008), showed that the engine of the tested car reached the oil temperature of $\approx 80{ }^{\circ} \mathrm{C}$ at the end of the UDC phase. Similar results are presented in paper (Suarez-Bertoa et al. 2014). Thus, for the EUDC cycle, the engine's thermal state is similar for both cold start and hot start tests.
The values of the calculated repeatability parameters for the NEDC test results from the cold start are set out in Table 7, and from the hot start in Table 8. Table 9 lists the allowable differences, $\Delta$, between the results of two emission measurements under repeatability conditions for the analyzed exhaust gas components. Figs. 13, 14, 15, 16, 17, and 18 show the results of the repeatability limits, $r$, and absolute differences for the two emission measurements of the analyzed exhaust components. Figure 19 shows the values of the $\mathrm{CV}$ of the specific emission measurements of the analyzed exhaust components for each phase and for the entire test.

The $r$ values of the $\mathrm{CO}$ and $\mathrm{NO}_{\mathrm{X}}$ emissions for the tested car were higher for the UDC phase of the NEDC tests, implemented from the hot start in relation to the results obtained from the cold start (Figs. 13 and 15).

For cold start tests (Table 7), the highest value of $s_{\mathrm{r}}$ for the entire NEDC test was obtained for the emissions of $\mathrm{CO}_{2}$ with the value of $0.99 \mathrm{~g} / \mathrm{km}$, and the lowest value $s_{\mathrm{r}}=0.0012 \mathrm{~g} / \mathrm{km}$ for $\mathrm{CH}_{4}$. For the remaining measured exhaust components, the standard deviation values were small and amounted to $\approx$ $0.0025 \mathrm{~g} / \mathrm{km}$ for $\mathrm{NO}_{\mathrm{X}}, \mathrm{NMHC}$, and THC. In the case of $\mathrm{CO}$
Table 7 Parameters of repeatability analysis (NEDCcold start tests)

\begin{tabular}{cllllll}
\hline Parameter & $\begin{array}{l}\text { Values for } \\
\text { THC }\end{array}$ & $\begin{array}{l}\text { Values for } \\
\mathrm{CH}_{4}\end{array}$ & $\begin{array}{l}\text { Values for } \\
\text { NMHC }\end{array}$ & $\begin{array}{l}\text { Values for } \\
\mathrm{NO}_{\mathrm{X}}\end{array}$ & $\begin{array}{l}\text { Values for } \\
\mathrm{CO}\end{array}$ & $\begin{array}{l}\text { Values for } \\
\mathrm{CO}_{2}\end{array}$ \\
\hline $\begin{array}{c}x_{\mathrm{av}} \\
(\mathrm{g} / \mathrm{km})\end{array}$ & 0.048 & 0.005 & 0.043 & 0.018 & 0.443 & 202.513 \\
$\begin{array}{r}x_{\min } \\
(\mathrm{g} / \mathrm{km})\end{array}$ & 0.046 & 0.005 & 0.041 & 0.016 & 0.439 & 201.411 \\
$\begin{aligned} x_{\max } \\
(\mathrm{g} / \mathrm{km})\end{aligned}$ & 0.051 & 0.005 & 0.046 & 0.021 & 0.449 & 203.331 \\
$R_{x}(\mathrm{~g} / \mathrm{km})$ & 0.005 & 0.0002 & 0.005 & 0.005 & 0.009 & 1.921 \\
$s_{\mathrm{r}}(\mathrm{g} / \mathrm{km})$ & 0.00258 & 0.00012 & 0.0024 & 0.0025 & 0.0049 & 0.99 \\
$\mathrm{CV}(\%)$ & 5.43 & 2.56 & 5.76 & 13.53 & 1.11 & 0.489 \\
$r(\mathrm{~g} / \mathrm{km})$ & 0.0072 & 0.0003 & 0.0069 & 0.007 & 0.0138 & 2.7758 \\
\hline
\end{tabular}


Table 8 Parameters of repeatability analysis (NEDC—hot start tests)

\begin{tabular}{lllllll}
\hline Parameter & $\begin{array}{l}\text { Values for } \\
\text { THC }\end{array}$ & $\begin{array}{l}\text { Values for } \\
\mathrm{CH}_{4}\end{array}$ & $\begin{array}{l}\text { Values for } \\
\text { NMHC }\end{array}$ & $\begin{array}{l}\text { Values for } \\
\mathrm{NO}_{\mathrm{X}}\end{array}$ & $\begin{array}{l}\text { Values for } \\
\mathrm{CO}\end{array}$ & $\begin{array}{l}\text { Values for } \\
\mathrm{CO}_{2}\end{array}$ \\
\hline $\begin{array}{r}x_{\mathrm{av}} \\
(\mathrm{g} / \mathrm{km})\end{array}$ & 0.007 & 0.003 & 0.004 & 0.006 & 0.169 & 186.29 \\
$\underset{\min }{(\mathrm{g} / \mathrm{km})}$ & 0.006 & 0.002 & 0.003 & 0.002 & 0.15 & 185.43 \\
$x_{\max }^{(\mathrm{g} / \mathrm{km})}$ & 0.009 & 0.003 & 0.005 & 0.009 & 0.195 & 186.895 \\
$R_{x}(\mathrm{~g} / \mathrm{km})$ & 0.003 & 0.001 & 0.002 & 0.006 & 0.045 & 1.465 \\
$S_{\mathrm{r}}(\mathrm{g} / \mathrm{km})$ & 0.00168 & 0.0005 & 0.0012 & 0.0031 & 0.0234 & 0.765 \\
$\mathrm{CV}(\%)$ & 25.66 & 16.31 & 33.45 & 56.91 & 13.82 & 0.41 \\
$r(\mathrm{~g} / \mathrm{km})$ & 0.0047 & 0.0013 & 0.0035 & 0.0088 & 0.0655 & 2.1436 \\
\hline
\end{tabular}

emission, the absolute standard deviation was $\approx 0.0049 \mathrm{~g} / \mathrm{km}$ for the cold start tests.

For hot start tests (Table 8), the highest value of $s_{\mathrm{r}}$ for the entire NEDC test was, as before, obtained for the emissions of $\mathrm{CO}_{2}$ with the value of $0.765 \mathrm{~g} / \mathrm{km}$, and the lowest value $s_{\mathrm{r}}=$ $0.0005 \mathrm{~g} / \mathrm{km}$ for $\mathrm{CH}_{4}$. For THC and $\mathrm{NMHC}$, the standard deviation values were lower than those from a cold start and were respectively $\approx 0.0017$ and $\approx 0.0012 \mathrm{~g} / \mathrm{km}$. With regard to the results of the $\mathrm{NO}_{\mathrm{X}}$ emission, the standard deviation from the hot start test was greater than for the cold start tests (by $\approx$ $25 \%$ ) and amounted to $0.0031 \mathrm{~g} / \mathrm{km}$. A significant value of the standard deviation for $\mathrm{CO}$ emissions of $\approx 0.023 \mathrm{~g} / \mathrm{km}$ was obtained in the case of hot start tests. This value was 4.5 times greater than the value obtained for cold start tests, which may be related to the abovementioned engine control strategy and conversion efficiency of the catalytic reactor. Similar results were obtained by the authors of paper (Clairotte et al. 2013), where for a passenger car (Euro 4) fueled with E5 in the NEDC cold start test (at $22^{\circ} \mathrm{C}$ ), the following values of standard deviations were obtained: $0.007 \mathrm{~g} / \mathrm{km}$ for $\mathrm{HC}, 0.007 \mathrm{~g} /$ $\mathrm{km}$ for $\mathrm{NMHC}, 0.127 \mathrm{~g} / \mathrm{km}$ for $\mathrm{CO}, 0.003 \mathrm{~g} / \mathrm{km}$ for $\mathrm{NO}_{\mathrm{X}}$, and $0.9 \mathrm{~g} / \mathrm{km}$ for $\mathrm{CO}_{2}$.

Values of $r$ for the NEDC cycle during hot start tests (Table 8), were higher for $\mathrm{CH}_{4}, \mathrm{NO}_{\mathrm{X}}$, and $\mathrm{CO}$ (respectively: $0.0013 \mathrm{~g} / \mathrm{km}, 0.0088 \mathrm{~g} / \mathrm{km}, 0.0655 \mathrm{~g} / \mathrm{km})$ in relation to those measures obtained from the cold start $(0.0003 \mathrm{~g} / \mathrm{km}, 0.007 \mathrm{~g} /$ $\mathrm{km}, 0.0138 \mathrm{~g} / \mathrm{km})$. For the remaining exhaust components analyzed, the repeatability limit for cold start tests was higher than for hot start tests (by $\approx 53 \%$ for $\mathrm{THC}$, by $\approx 97 \%$ for $\mathrm{NMHC}$, and by $\approx 29 \%$ for $\mathrm{CO}_{2}$ ).

The highest values of repeatability limits were obtained for the analyzed pollutants in the urban part of the UDC, where a greater variability of the test results occurs. In hot start tests for $\mathrm{CO}$ (Fig. 13), $\mathrm{CH}_{4}$ (Fig. 16), and $\mathrm{NO}_{\mathrm{X}}$ (Fig. 15), the value of this parameter was higher than in the cold start tests. This may be related to the mentioned engine control strategy.

CV values (Fig. 19) for the hot start tests were higher than those obtained from the cold start (in the cold start tests, the CV did not exceed $10 \%$, except for
$\mathrm{NO}_{\mathrm{X}}$ ). The lowest $\mathrm{CV}$ values were obtained for specific emission of $\mathrm{CO}_{2}$, both for the entire test, as well as for each of its phases (the maximum value of this parameter was $\approx 0.6 \%$ ). Low variability was also evident in the specific emission of $\mathrm{CO}(\mathrm{CV}$ for the entire cold start test was $\approx 1 \%$, while for the hot start was $\approx 14 \%$ ). The highest $\mathrm{CV}$ values were obtained for specific emission of $\mathrm{CH}_{4}(\approx 138 \%$ in the EUDC cycle from the cold start and $\approx 95 \%$ in the EUDC cycle from the hot start). High variability was also obtained for specific emission results of $\mathrm{NO}_{\mathrm{X}}$ for the hot start tests in the UDC cycle $(\approx 65 \%)$. For cold start tests, a high $\mathrm{CV}$ value $(\approx 21 \%)$ was obtained for specific emission of $\mathrm{THC}$ in the EUDC cycle. For the entire NEDC cold start, the highest variability $(\mathrm{CV}=13 \%)$ was observed in the specific emission of $\mathrm{NO}_{\mathrm{X}}$. Similarly, for the hot start for the entire NEDC test, the greatest variation was obtained for $\mathrm{NO}_{\mathrm{X}}(\mathrm{CV}=57 \%)$. It should be borne in mind that the values of the CVs depend on the absolute values of the pollutants emissions measured, hence their values depend on the accuracy of the measuring equipment used, which is of particular importance for the exhaust components for which the absolute values of the emissions are low.

Table 9 Allowable differences, $\Delta$, between the results of two emission measurements under repeatability conditions for the analyzed exhaust gas components

\begin{tabular}{lll}
\hline \multirow{2}{*}{ Exhaust component } & \multicolumn{2}{l}{ Allowable difference $\Delta$} \\
\cline { 2 - 3 } & Cold start test & Hot start test \\
\hline $\mathrm{THC}$ & $\Delta \leq 0.0072 \mathrm{~g} / \mathrm{km}$ & $\Delta \leq 0.0047 \mathrm{~g} / \mathrm{km}$ \\
$\mathrm{NMHC}$ & $\Delta \leq 0.0069 \mathrm{~g} / \mathrm{km}$ & $\Delta \leq 0.0035 \mathrm{~g} / \mathrm{km}$ \\
$\mathrm{CH}_{4}$ & $\Delta \leq 0.0003 \mathrm{~g} / \mathrm{km}$ & $\Delta \leq 0.0013 \mathrm{~g} / \mathrm{km}$ \\
$\mathrm{NO}_{\mathrm{X}}$ & $\Delta \leq 0.007 \mathrm{~g} / \mathrm{km}$ & $\Delta \leq 0.0088 \mathrm{~g} / \mathrm{km}$ \\
$\mathrm{CO}$ & $\Delta \leq 0.0138 \mathrm{~g} / \mathrm{km}$ & $\Delta \leq 0.0655 \mathrm{~g} / \mathrm{km}$ \\
$\mathrm{CO}_{2}$ & $\Delta \leq 2.7758 \mathrm{~g} / \mathrm{km}$ & $\Delta \leq 2.1436 \mathrm{~g} / \mathrm{km}$ \\
\hline
\end{tabular}


Fig. 13 Results of the repeatability limits, $r$, and absolute differences, $\Delta$, for the two emission results of $\mathrm{CO}$ from the cold and hot start tests

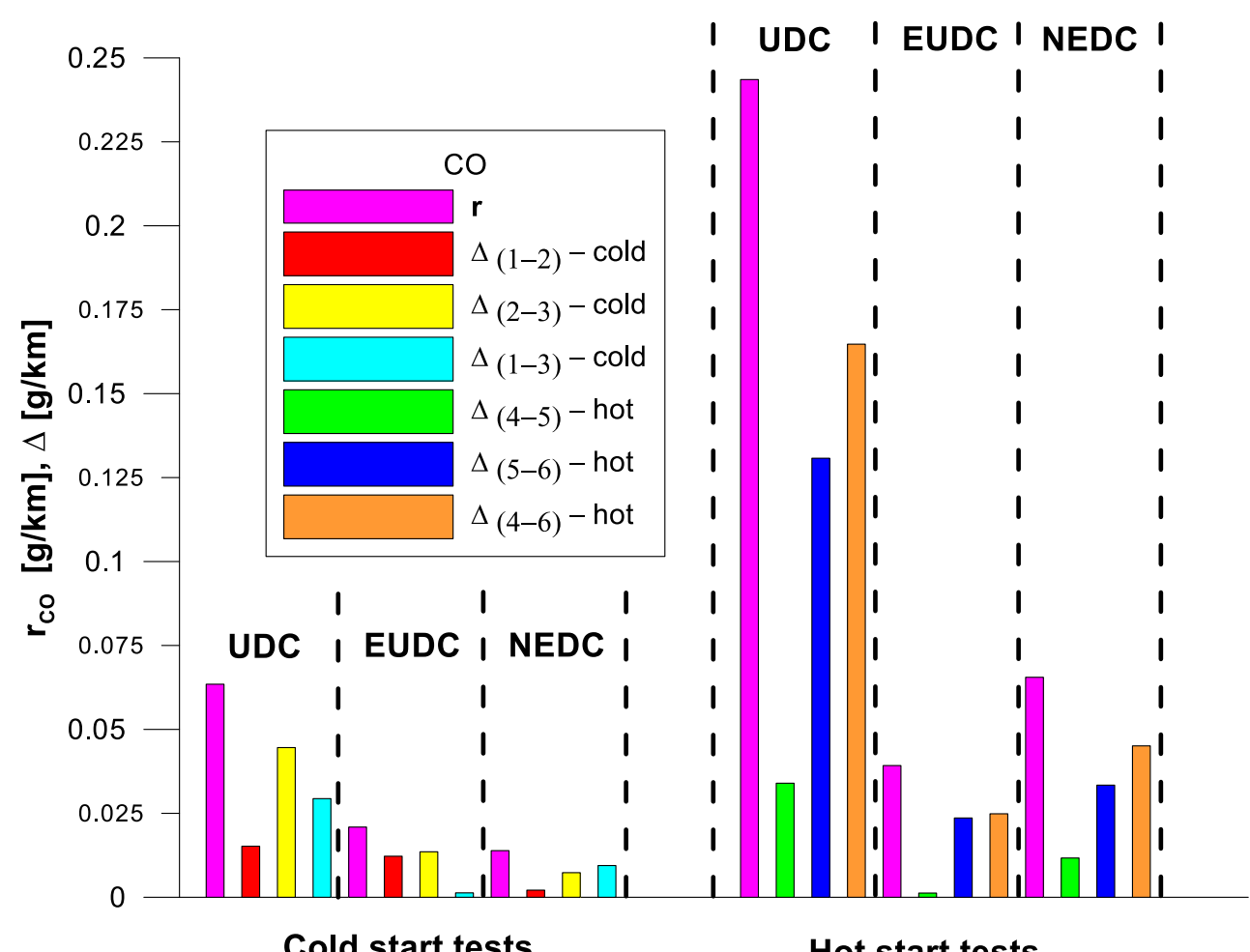

Hot start tests

\section{Conclusions}

The paper presents research on the accuracy of the results for exhaust pollutants emission, conducted under repeatability conditions for a small number of tests. For this purpose, a passenger car with Euro 4 homologation was used; moreover, the results of measurements proved that despite the mileage it still met the Euro 4 emission limits. The analysis included tests
Fig. 14 Results of the repeatability limits, $r$, and absolute differences, $\Delta$, for the two emission measurements of THC from the cold and hot start tests

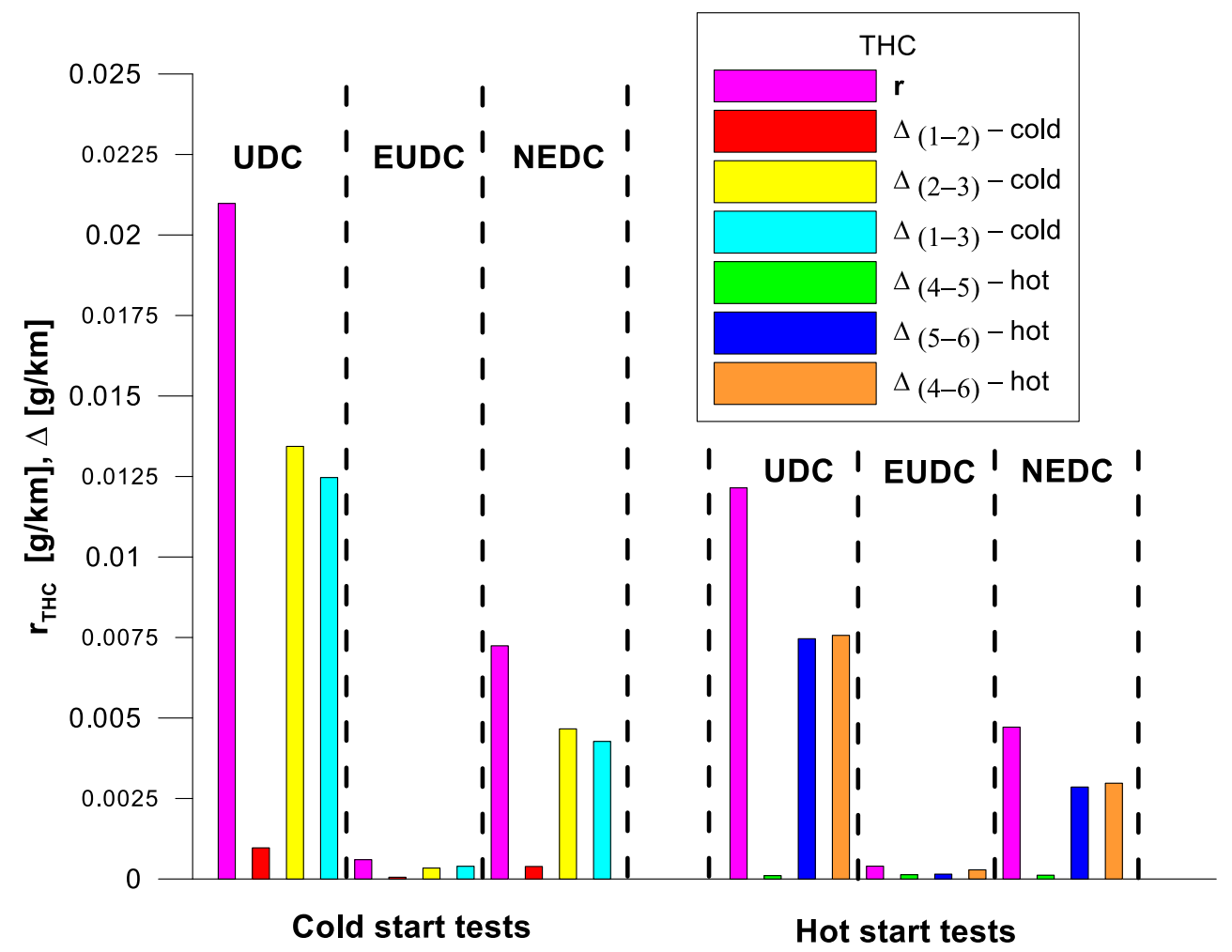


Fig. 15 Results of the repeatability limits, $r$, and absolute differences, $\Delta$, for the two emission measurements of $\mathrm{NO}_{\mathrm{X}}$ from the cold and hot start tests

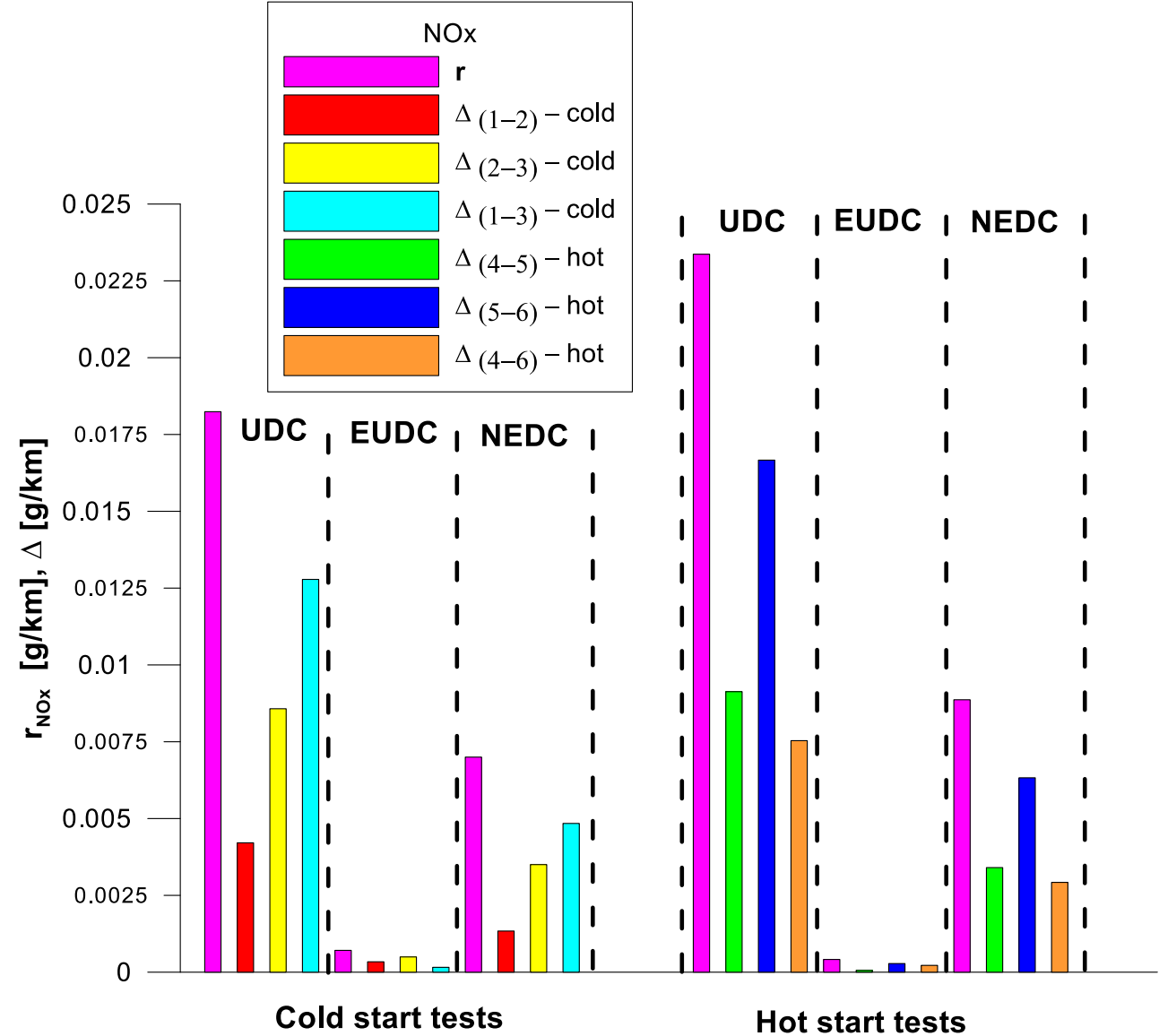

performed in the climate chamber according to the NEDC test both from cold (coolant temperature of $21 \pm 1{ }^{\circ} \mathrm{C}$ ) and hot (coolant temperature of $90 \pm 2{ }^{\circ} \mathrm{C}$ ) starts. For the measured exhaust components (CO, THC, $\mathrm{CH}_{4}, \mathrm{NMHC}, \mathrm{NO}_{\mathrm{X}}, \mathrm{CO}_{2}$ ),
Fig. 16 Results of the repeatability limits, $r$, and absolute differences, $\Delta$, for the two emission measurements of $\mathrm{CH}_{4}$ from the cold and hot start tests

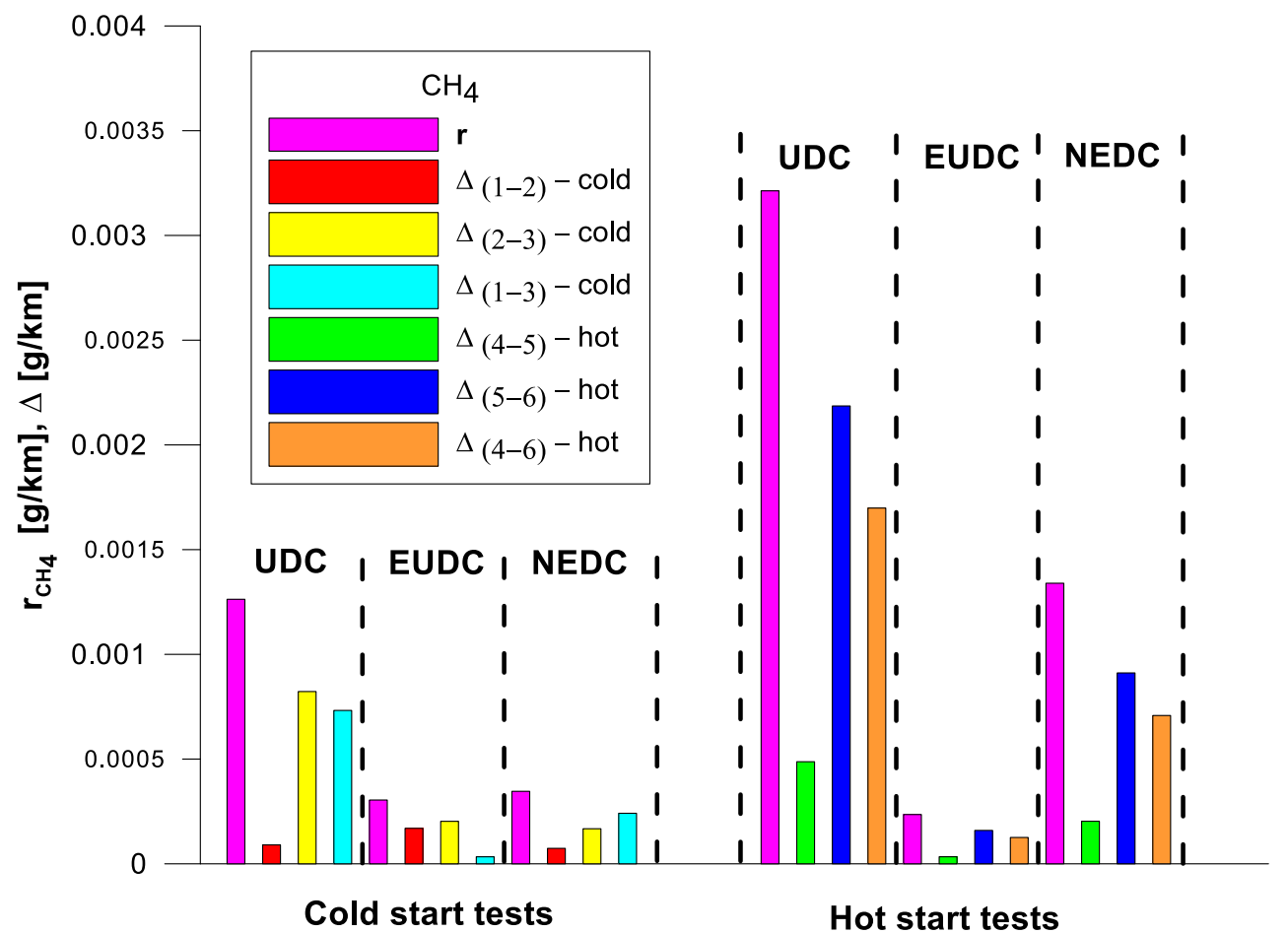


Fig. 17 Results of the

repeatability limits, $r$, and

absolute differences, $\Delta$, for the two emission measurements of $\mathrm{CO}_{2}$ from the cold and hot start tests
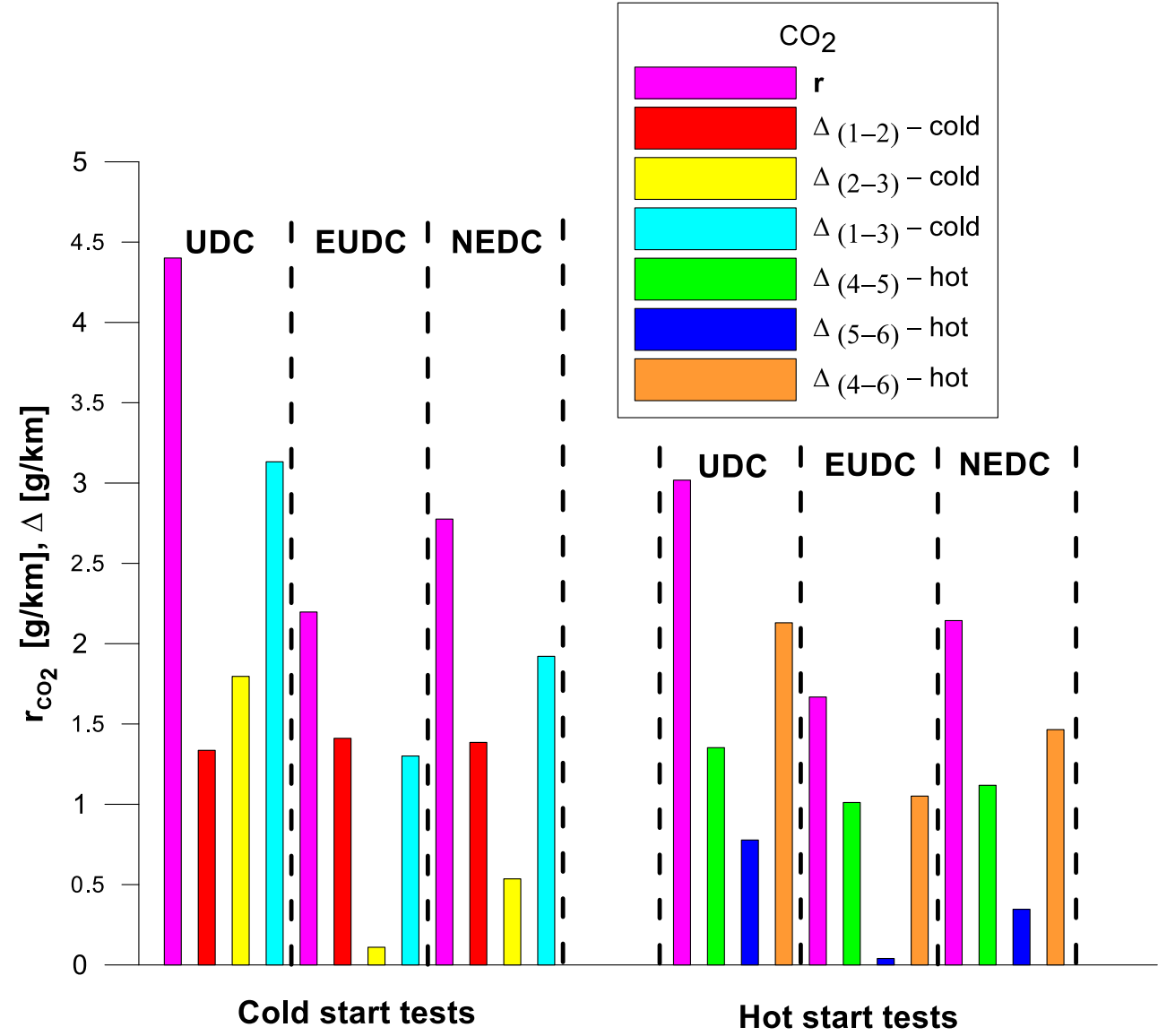

Hot start tests
Fig. 18 Results of the repeatability limits, $r$, and absolute differences, $\Delta$, for the two emission measurements of NMHC from the cold and hot start tests

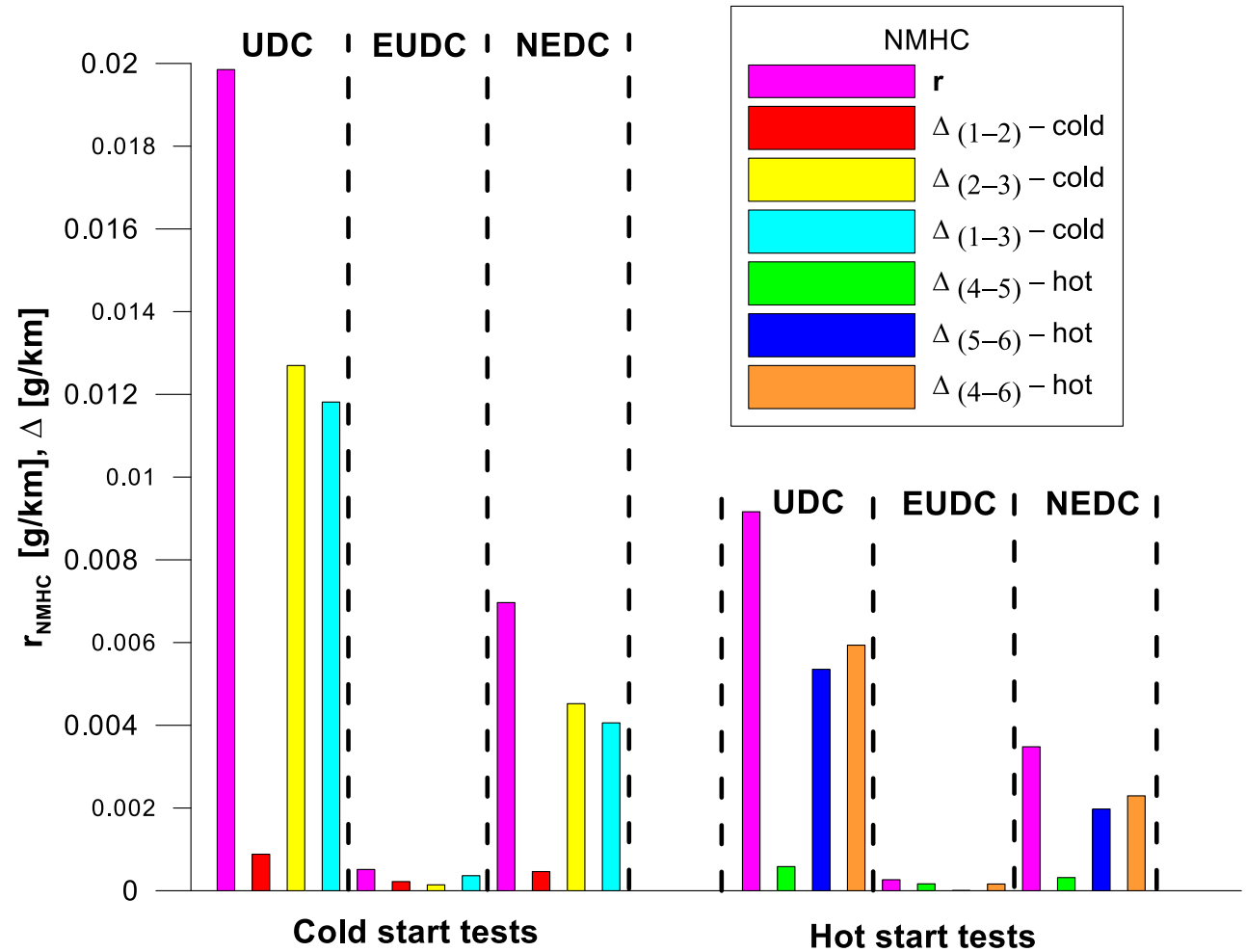


Fig. 19 The values of the CV of the analyzed exhaust components for both of the phases and for the entire test

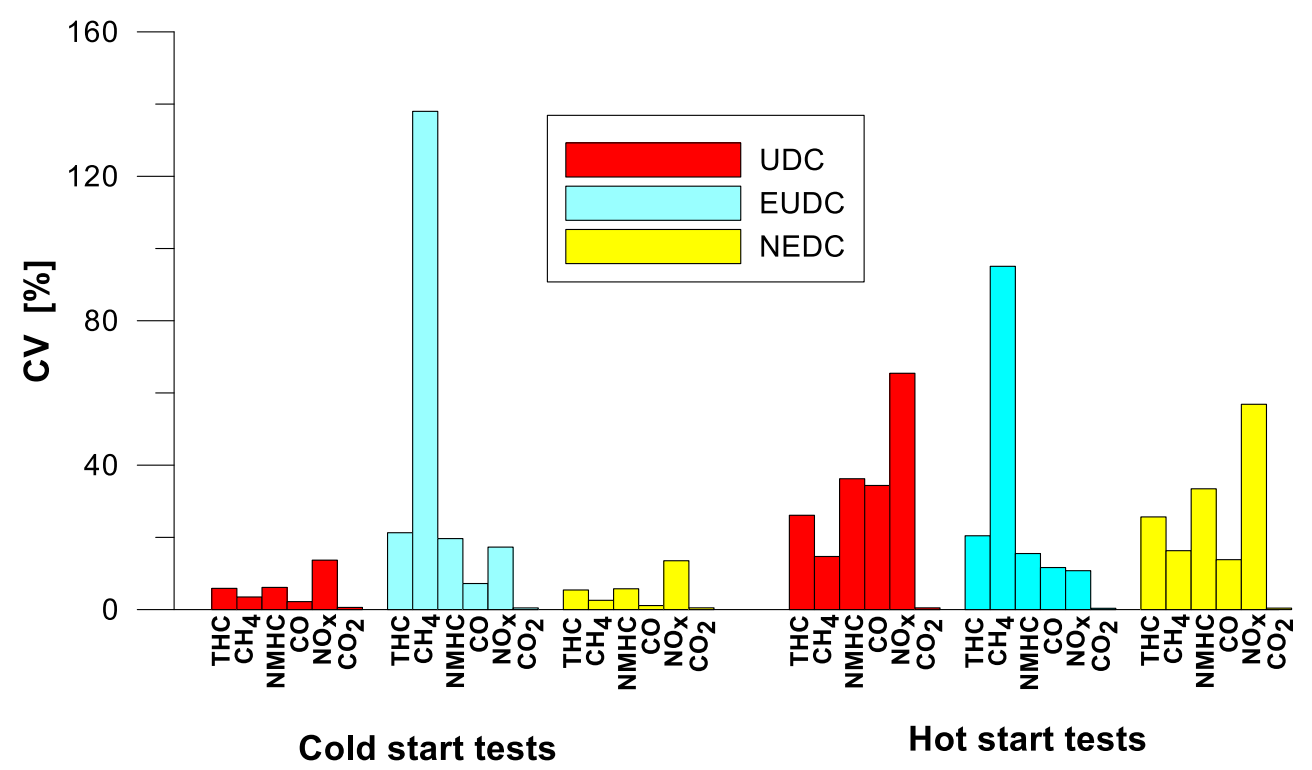

the accuracy parameters were indicated for the first phase of the test (UDC), the second phase of the test (EUDC), and for the entire test (NEDC).

The conducted research allows us to formulate the following conclusions:

- A proper interpretation of the results of the pollutant emission tests based on the mean value, in particular for a small number of tests, requires the results repeatability analysis.

- A temperature of the engine at the test start do not affect significantly the emission values recorded in phase 2 of the cycle (EUDC).

- A higher engine temperature at the test start is associated with greater variability $(\mathrm{CV})$ of the results obtained for the NEDC cycle.

- The results obtained in phase 1 (UDC) have the greatest impact on the results of the emission for the entire test.

- A higher engine temperature at the test start is associated with lower values of repeatability $r$ for the NEDC cycle and $\mathrm{CO}, \mathrm{CH}_{4}$, and $\mathrm{NO}_{\mathrm{X}}$ emissions.

- For a more complete assessment of the pollutant emission results obtained for a small number of measurements, i.e., when they may be subjected to a large scattering, it is advantageous, according to the authors, to determine the parameter allowing the evaluation of repeatability of obtained values. The use of that coefficient can be helpful in the evaluation of the repeatability of the results obtained by various laboratories.

- The coefficient of variation (CV) that is used in such cases for assessing variability is unsuitable when very low emission values are recorded. However, such achievements are desirable from environment protection point of view.

- Since the CV values depend on their average values, the authors suggest to define the threshold coefficient of variation (CVL) determined relatively to the standard emission limit value of a given exhaust compound (L), instead of the average value. The values of the proposed CVL do not depend on the mean values, so they can be used for evaluation of repeatability of the test results.

- Currently, there are no satisfactory standards specifying the $\mathrm{CV}$ values relating to the results of pollutant emission obtained during steady-state driving cycles. In the case of the standard of Euro 4, which was implemented for the tested vehicle, the maximum threshold CVL should be less than $20 \%$.

- For the conducted cold start tests, the values of the defined here $\mathrm{CVL}$ for $\mathrm{THC}, \mathrm{CO}$, and $\mathrm{NO}_{\mathrm{X}}$ emissions are respectively equal to $2.6,0.5$, and $3.1 \%$. The obtained values of CVL for harmful exhaust compound emission results $\left(\mathrm{CO}, \mathrm{THC}, \mathrm{NO}_{\mathrm{X}}\right)$ are acceptable for cold start tests.

Based on the analysis of obtained test results, authors conclude that the performing procedures for driving cycles have been implemented correctly. The steps taken to establish the satisfactory values of the coefficients of variation separately for each analyzed exhaust component appear to be desired. The research carried out by the authors show that the selection of acceptable values of this coefficient should consider the thermal state of the engine at test start. This objective requires a statistical series of results obtained from various laboratories. 
Funding information This work was supported by The Ministry of Infrastructure and Development under the Eastern Poland Development Operational Program including European Regional Development Fund, which financed the research instruments.

\section{Glossary}

$\begin{array}{ll}\mathrm{CH}_{4} & \text { Methane } \\ \mathrm{CO} & \text { Carbon monoxide } \\ \mathrm{CO}_{2} & \text { Carbon dioxide } \\ \mathrm{CV} & \text { Coefficient of variation } \\ \mathrm{CV}_{\mathrm{L}} & \text { Threshold coefficient of variation } \\ \mathrm{CVS} & \text { Constant volume sampling } \\ \text { EUDC } & \text { Extra Urban Driving Cycle } \\ \text { NEDC } & \text { New European Driving Cycle } \\ \text { NMHC } & \text { Non-methane hydrocarbons } \\ \text { NOx } & \text { Nitrogen oxides } \\ r & \text { Repeatability limit } \\ \text { R\&D } & \text { Research and development } \\ \text { RDE } & \text { Real Driving Emissions } \\ \mathrm{R}_{\mathrm{x}} & \left.\text { Range ( } x_{\text {max }}-x_{\text {min }}\right) \\ S_{\mathrm{r}} & \text { Repeatability standard deviation } \\ \text { THC } & \text { Total hydrocarbons } \\ \text { UDC } & \text { Urban Driving Cycle } \\ \text { WLTC } & \text { World Harmonized Light Vehicles Test Cycle } \\ \text { WLTP } & \text { Worldwide Harmonized Light Vehicles Test } \\ & \text { Procedure } \\ x_{\mathrm{av}} & \text { Mean value } \\ x_{\text {max }} & \text { Maximum value } \\ x_{\text {min }} & \text { Minimum value } \\ \Delta & \text { Allowable differences, between the results of two } \\ & \text { emission measurements under repeatability } \\ \lambda & \text { conditions } \\ & \text { Relative air-fuel ratio } \\ & \end{array}$

Open Access This article is distributed under the terms of the Creative Commons Attribution 4.0 International License (http:// creativecommons.org/licenses/by/4.0/), which permits unrestricted use, distribution, and reproduction in any medium, provided you give appropriate credit to the original author(s) and the source, provide a link to the Creative Commons license, and indicate if changes were made.

\section{References}

Andersson J, May J, Favre C, Bosteels D, De Vries S, Heaney M, Keenan M, Mausell J (2014) On-road and chassis dynamometer evaluations of emissions from two Euro 6 diesel vehicles. SAE Int J Fuels Lubr 7(3):919-934. https://doi.org/10.4271/2014-01-2826

AVL (2010) CVS i60. User's Guide. AVL, Graz

AVL (2013) AMA i60 exhaust measurement system. Specification. AVL, Graz

AVL (2014) Service Manual AVL- ROADSIM 48"
Balawender K, Jaworski A, Kuszewski H, Lejda K, Ustrzycki A (2016) An assessment of consistence of exhaust gas emission test results obtained under controlled NEDC conditions. IOP Conference Series: Materials Science and Engineering, 148:1-10. https://doi. org/10.1088/1757-899X/148/1/012059

Bielaczyc P, Merkisz J, Pielecha J (2001) Effects of unheated engine on emission of toxic exhaust gases (in Polish). Poznań University of Technology Press, Poznań

Bielaczyc P, Woodburn J, Szczotka A (2014) The WLTP as a new tool for the evaluation of $\mathrm{CO}_{2}$ emissions. FISITA World Automotive Congress 2014, Maastricht, Netherlands. www.fisita2014.com/ programme/sessions/F2014-CET-139. https://doi.org/10.2478/aep2014-0026

Bielaczyc P, Woodburn J, Szczotka A (2015) A comparison of Carbon Dioxide exhaust emissions and fuel consumption for vehicles tested over the NEDC, FTP-75 and WLTC chassis dynamometer test cycles. SAE Technical Paper 2015-01-1065. https://doi.org/10.4271/ 2015-01-1065

Chłopek Z, Rostkowski J (2015) Non-repeatability of exhaust emission test results. Combustion Engines 163(4):92-100 ISSN 2300-9896

Chłopek Z, Szczepański T (2015) Rating causes the non-repeatability of an internal combustion engine operating states in the sets of his work conditions. Combust Engines 162(3):708-711 ISSN 2300-9896

Clairotte M, Adam TW, Zardini AA, Manfredi U, Martini G, Krasenbrink A, Vicet A, Tournie E, Astorga C (2013) Effects of low temperature on the cold start gaseous emissions from light duty vehicles fuelled by ethanol-blended gasoline. Appl Energy 102:44-54

Concawe (2016) Gasoline direct injection particulate study. Report no. 10/16. Brussels: Concawe

European Commission (2007) Regulation (EC) No 715/2007 of the European Parliament and of the council of 20 June 2007 on type approval of motor vehicles with respect to emissions from light passenger and commercial vehicles (Euro 5 and Euro 6) and on access to vehicle repair and maintenance information

European Commission (2015) Regulation No83 of the Economic Commission for Europe of the United Nations (UNECE) Uniform provisions concerning the approval of vehicles with regard to the emission of pollutants according to engine fuel requirements. Off J Eur Union vol 58

European Commission (2017) Commission Regulation (EU) 2017/1151. supplementing Regulation (EC) No 715/2007 of the European Parliament and of the Council on type-approval of motor vehicles with respect to emissions from light passenger and commercial vehicles (Euro 5 and Euro 6) and on access to vehicle repair and maintenance information, amending Directive 2007/46/EC of the European Parliament and of the Council, Commission Regulation (EC) No 692/2008 and Commission Regulation (EU) No 1230/2012 and repealing Commission Regulation (EC) No 692/2008

Favez JY, Weilenmann M, Stilli J (2009) Cold start extra emissions as a function of engine stop time: evolution over the last 10 years. Atmos Environ 43:996-1007

Giechaskiel B, Dilara P, Andersson J (2008) Particle measurement programme (PMP) light-duty inter-laboratory exercise: repeatability and reproducibility of the particle number method. Aerosol Sci Technol 42(7):528-543. https://doi.org/10.1080/ 02786820802220241

Heinfellner H, Konrad C, Lichtblau G, Schodl B, Stranner G, Winter R (2016) Legal obligations relating to emission measurements in the EU automotive sector, Study for the EMIS Committee, European Parliament Directorate General for Internal Policies, Policy department A, Brussels. www.europarl.europa.eu/RegData/etudes/STUD/ 2016/578996/IPOL_STU(2016)578996_EN.pdf 
Joumard R, Laurikko J, Le Han T, Geivanidis S, Samaras Z, Merétei T, Devaux P, André JM, Cornelis E, Lacour S, Prati MV, Vermeulen R, Zallinger M (2009) Accuracy of exhaust emission factor measurements on chassis dynamometer. J Air Waste Manag Assoc 59(6): 695-703

Joumard R, Andre M, Laurikko J, Anh TL, Geivanidis S, et al (2013) Accuracy of exhaust emission measurements on vehicle bench. Artemis deliverable 2. 2013

Kan ZC, Lou DM, Cao ZZ, Hu ZY, Liu S, Yang ZH (2017) Effects of altitude on combustion characteristic during cold start of heavy-duty diesel engine. Int J Automot Technol 18(2):209-217. https://doi.org/ $10.1007 / \mathrm{s} 12239-017-0020-\mathrm{x}$

Kim H, Lee J (2011) Quantitative analysis of vehicle particle emission by using calibrated CPC system. J Mech Sci Technol 25(11):29592967

Kuszewski H, Jaworski A, Ustrzycki A (2017a) Lubricity of ethanoldiesel blends - study with the HFRR method. Fuel 208:491-498. https://doi.org/10.1016/j.fuel.2017.07.046

Kuszewski H, Jaworski A, Ustrzycki A, Lejda K, Balawender K, Wos'P. (2017b) Use of the constant volume combustion chamber to examine the properties of autoignition and derived cetane number of mixtures of diesel fuel and ethanol. Fuel 200:564-575

Kwak H, Myung CL, Park S (2007) Experimental investigation on the time resolved THC emission characteristics of liquid phase LPG injection (LPLi) engine during cold start. Fuel 86:1475-1482

Ligterink N, van Mensch P, Cuelenaere RFA (2016) NEDC-WLTP comparative testing. TNO R11285. Netherlands

Marotta A, Pavlovic J, Ciuffo B, Serra S, Fontaras G (2015) Gaseous emissions from light-duty vehicles: moving from NEDC to the new WLTP test procedure. Environ Sci Technol 49(14):8315-8322

Martini G, Manfredi U, Krasenbrink A, Stradling R, Zemroch PJ, Rose $\mathrm{KD}$, Hass H, Maas H (2013) Effect of oxygenates in gasoline on fuel consumption and emissions in three Euro 4 passenger cars. JRC/ EUCAR/CONCAWE Study. Final report. Joint Research Centre of the European Commission

Mast P (2014) Worldwide harmonized light vehicles test procedures. What is WLTP and how does it differ from NEDC? www. ukintpress-conferences.com/uploads/SPKEX14/d1_s1_p3_pascal_ mast.pdf

May J, Bosteels D, Favre C (2014) A comparison of light-duty vehicle emissions over different test cycles and in real driving conditions. SAE Technical Paper No 2014-01-1581

McCormick RL, Williams A, Ireland J, Brimhall M, Hayes RR (2006) Effects of Biodiesel Blends on Vehicle Emissions. Fiscal Year 2006
Annual Operating Plan Milestone10.4. Milestone Report NREL/MP-540-40554

Merkisz J, Rymaniak $Ł$ (2017) The assessment of vehicle exhaust emissions referred to $\mathrm{CO} 2$ based on the investigations of city buses under actual conditions of operation. Eksploatacja i Niezawodnosc Maintenance and Reliability; 19(4): 522-529. https://doi.org/10. 17531/ein.2017.4.5

Myung C, Lee H, Kwon S, Lee S, Jun J, Lee Y, Woo Y, Lee M, Bae G, Park S (2009) Interlaboratory correlation exercise on a light-duty diesel passenger vehicle to verify nano-particle emission characteristics by Korea particle measurement program. J Mech Sci Technol 23:729-738

Pelkmans L, Debal P (2006) Comparison of on-road emissions with emissions measured on chassis dynamometer test cycles. Transp Res Part D Transp Environ 11(Issue: 4):233-241

Pielecha J, Merkisz J, Markowski J, Jasiński R (2016) Analysis of passenger car emission factors in RDE tests. https://doi.org/10.1051/ e3sconf $/ 20161000073$

PN-ISO 5725-1 (2002) Accuracy (trueness and precision) of measurement methods and results-Part 1: General principles and definitions

PN-ISO 5725-2 (2002) Accuracy (trueness and precision) of measurement methods and results - Part 2: Basic method for the determination of repeatability and reproducibility of a standard measurement method

PN-ISO 5725-6 (2002) Accuracy (trueness and precision) of measurement methods and results-Part 6: Use in practice accuracy values

Shamim T (2011) Effect of engine exhaust gas modulation on the cold start emissions. Int J Automot Technol 12(4):475-487

Suarez-Bertoa R, Zardini AA, Astorga C (2014) Ammonia exhaust emissions from spark ignition vehicles over the New European Driving Cycle. Atmos Environ 97:43-53. https://doi.org/10.1016/j. atmosenv.2014.07.050

Suarez-Bertoa R, Zardini AA, Lilova V, Meyer D, Nakatani S, Hibel F, Ewers J, Clairotte M, Hill L, Astorga C (2015) Intercomparison of real-time tailpipe ammonia measurements from vehicles tested over the new world-harmonized light-duty vehicle test cycle (WLTC). Environ Sci Pollut Res 22:7450-7460. https://doi.org/10.1007/ s11356-015-4267-3

Torregrosa AJ, Broatch A, Olmeda P, Romero C (2008) Assessment of the influence of different cooling system configurations on engine warm-up, emissions and fuel consumption. Int $\mathrm{J}$ Automot Technol 9(4):447-458 